EDIMAR EMILIANO SOARES RAMALHO

\title{
DETERMINANTES DA CONTRIBUIÇÃO PREVIDENCIÁRIA DOS TRABALHADORES AUTÔNOMOS NO BRASIL
}

Dissertação apresentada à Universidade Federal de Viçosa, como parte das exigências do Programa de Pós-Graduação em Economia, para obtenção do título de Magister Scientiae.

VIÇOSA

MINAS GERAIS - BRASIL

2015 
Ficha catalográfica preparada pela Biblioteca Central da Universidade Federal de Viçosa - Câmpus Viçosa

$\mathrm{T}$

Ramalho, Edimar Emiliano Soares, 1990-

R165d

Determinantes da contribuição previdenciária dos

2015 trabalhadores autônomos no Brasil / Edimar Emiliano Soares Ramalho. - Viçosa, MG, 2015.

xii, 66f. : il. ; $29 \mathrm{~cm}$.

Orientador : Elvanio Costa de Souza.

Dissertação (mestrado) - Universidade Federal de Viçosa.

Referências bibliográficas: f.59-66.

1. Previdência social. 2. Trabalhadores autônomos. 3. Demanda (Economia). I. Universidade Federal de Viçosa. Departamento de Economia. Programa de Pós-graduação em Economia. II. Título.

CDD 22. ed. 368.40981 


\section{DETERMINANTES DA CONTRIBUIÇÃO PREVIDENCIÁRIA DOS TRABALHADORES AUTÔNOMOS NO BRASIL}

Dissertação apresentada à Universidade Federal de Viçosa, como parte das exigências do Programa de Pós-Graduação em Economia, para obtenção do título de Magister Scientiae.

APROVADA: 29 de maio de 2015. 
À Jaqueline 


\section{AGRADECIMENTOS}

Agradeço a Deus, por ter colocado pessoas especiais na minha vida e professores dedicados com minha carreira acadêmica. Em especial, minha família por ser o alicerce dessa conquista, demonstrando muito amor e admiração. Ao meu orientador, professor Elvanio, pela paciência e compreensão das minhas indagações.

Em geral, dedico a todos os colegas, primos, funcionários e todas as pessoas que passaram no meu caminho. Essa vitória veio para sacramentar o ensinamento e o desejo de sempre conhecer. A principal lição que levo para a vida é que ninguém toma suas titulações.

Por fim, deixo a frase do Augusto Cury para reflexão. "Um ladrão rouba um tesouro, mas não furta a inteligência. Uma crise destrói uma herança, mas não uma profissão. Não importa se você não tem dinheiro, você é uma pessoa rica, pois possui o maior de todos os capitais: a sua inteligência. Invista nela. Estude!" 


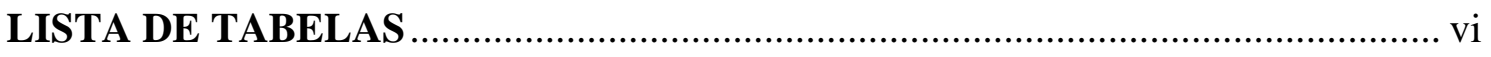

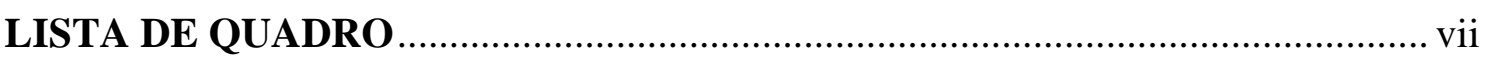

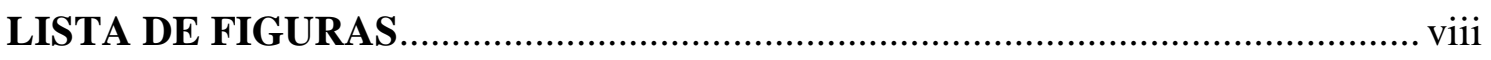

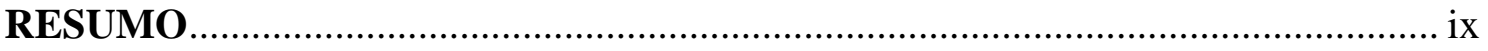

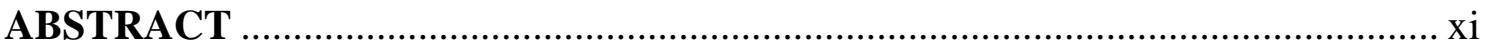

1. INTRODUÇÃ

1.1 Considerações Iniciais ............................................................................ 1

1.2 Problema e sua importância ...................................................................... 3

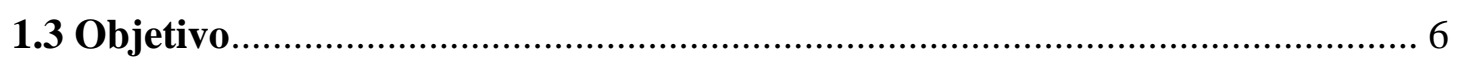

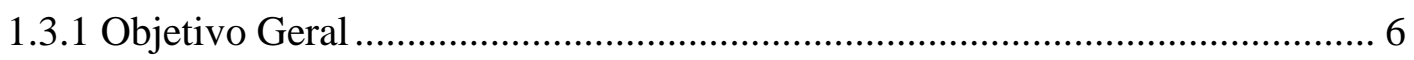

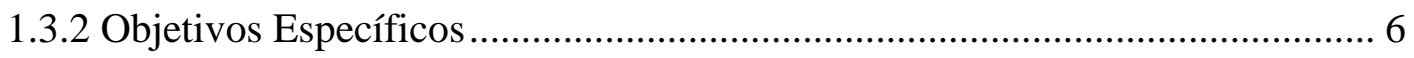

2. A PREVIDÊNCIA SOCIAL BRASILEIRA .................................................... 7

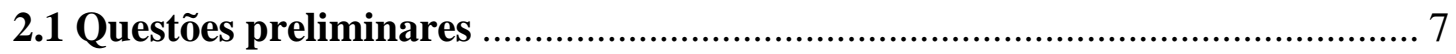

2.2 A composição da Previdência Social ............................................................ 10

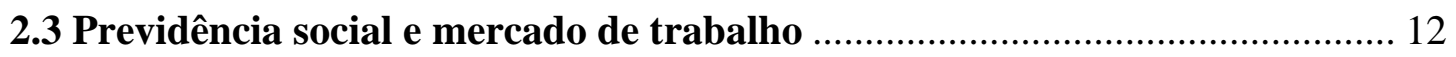

2.4 História da Previdência Social no Brasil .......................................................... 14

2.4.1 Primeira década da Previdência Social no Brasil e criação da Lei Eloy Chaves

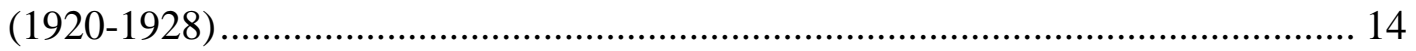

2.4.2 Mudanças no sistema, Governo Vargas e a Crise (1930-1988) ..................... 16

2.4.3 Em direção à universalização e reformas ....................................................... 22

$2.5 \mathrm{O}$ trabalhador autônomo e sua relação com a previdência social .................. 28

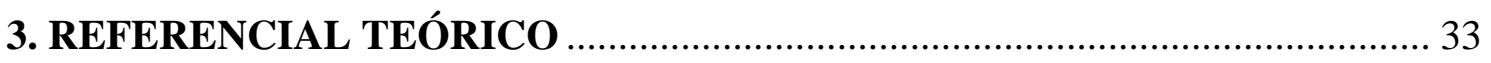

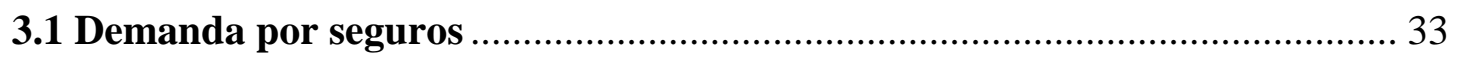

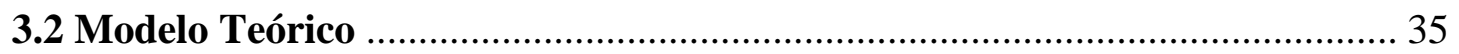

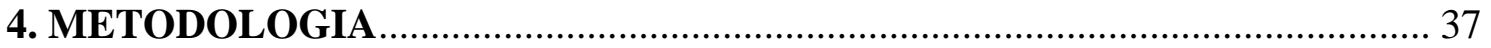

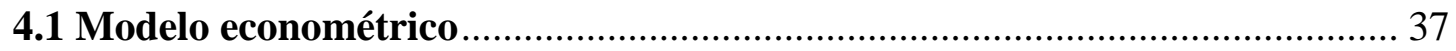

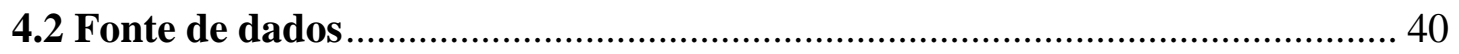

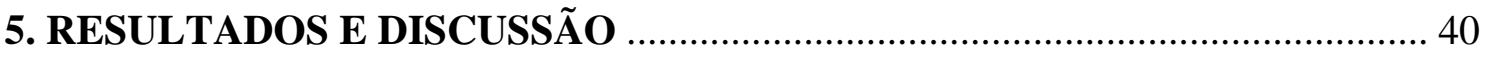

5.1 O trabalhador autônomo e sua relação com a previdência social .................. 40

5.2 Efeitos das características socioeconômicas e demográficas dos trabalhadores autônomos sobre sua decisão de contribuir para a previdência social .................50 
6. CONCLUSÃO.

REFERÊNCIAS BIBLIOGRÁFICAS

59 


\section{LISTA DE TABELAS}

Tabela 1 - Possibilidades de renda dos trabalhadores autônomos ao longo da vida segundo o estado de contribuição e o estado da natureza.............................................. 36 Tabela 2 - Número de trabalhadores, segundo a posição na ocupação no trabalho principal e contribuição para a previdência social, Brasil, 2013 41

Tabela 3 - Número de trabalhadores autônomos urbanos, segundo a contribuição para a previdência social, por categoria de trabalhador autônomo, Brasil, 2013. 42

Tabela 4 - Número de trabalhadores autônomos urbanos, segundo a contribuição para a previdência social, por gênero, Brasil, 2013

Tabela 5 - Número de trabalhadores autônomos urbanos, segundo a contribuição para a previdência social, por grupos de idade, Brasil, 2013

Tabela 6- Número de trabalhadores autônomos urbanos, segundo a contribuição para a previdência social, por grupos de anos de estudo, Brasil, 2013 45

Tabela 7- Número de trabalhadores autônomos urbanos, segundo a contribuição para a previdência social, por grandes regiões, Brasil, 2013

Tabela 8 - Número de trabalhadores autônomos urbanos, segundo a contribuição para a previdência social, por classes de renda, Brasil, 2013 (em salários mínimos de 2013 ${ }^{1}$ ) 47 Tabela 9 - Número de trabalhadores autônomos urbanos, segundo a contribuição para a previdência social, por grupo de atividade econômica, Brasil, 2013

Tabela 10 - Número de trabalhadores autônomos urbanos, segundo a contribuição para a previdência social, por composição domiciliar, Brasil, 2013 50

Tabela 11-Coeficientes estimados da equação que explica a contribuição previdenciária dos "outros autônomos" 52

Tabela 12- Coeficientes estimados da equação que explica a contribuição previdenciária dos "profissionais liberais" 


\section{LISTA DE QUADRO}

Quadro 1: História da previdência social 


\section{LISTA DE FIGURAS}

Figura 1 - Quadro analítico do Sistema previdenciário 10

Figura 2- População de 10 anos e mais ocupada, total e trabalhadores por conta própria - Brasil - 1940/2011 30

Figura 3 - Percentual de trabalhadores contribuintes para a previdência social, segundo a posição na ocupação no trabalho principal, Brasil, 2013 42 Figura 4 - Percentual de trabalhadores autônomos urbanos contribuintes para a previdência social, por tipo de trabalhador autônomo, Brasil, 2013

Figura 5 - Percentual de trabalhadores autônomos urbanos contribuintes para a previdência social, por gênero, Brasil, 2013

Figura 6 - Percentual de trabalhadores autônomos urbanos contribuintes para a previdência social, por grupos de idade, Brasil, 2013 45 Figura 7 - Percentual de trabalhadores autônomos urbanos contribuintes para a previdência social, por grupos de anos de estudo, Brasil, 2013 46 Figura 8 - Percentual de trabalhadores autônomos urbanos contribuintes para a previdência social, por grandes regiões, Brasil, 2013

Figura 9 - Percentual de trabalhadores autônomos urbanos contribuintes para a previdência social, por classes de renda, Brasil, 2013. 48 Figura 10 - Percentual de trabalhadores autônomos urbanos contribuintes para a previdência social, por grupo de atividade, Brasil, 2013 49

Figura 11 - Percentual de trabalhadores autônomos urbanos contribuintes para a previdência social, por composição domiciliar, Brasil, 2013 50 


\section{RESUMO}

RAMALHO, Edimar Emiliano Soares, M.Sc., Universidade Federal de Viçosa, maio de 2015. Determinantes da contribuição previdenciária dos trabalhadores autônomos no Brasil. Orientador: Elvanio Costa de Souza. Coorientador: Jader Fernandes Cirino.

Para o trabalhador autônomo, contribuir para a previdência social é uma questão de escolha, uma vez que ele tem a liberdade de contribuir ou não. $\mathrm{O}$ mesmo não ocorre com os empregados com carteira de trabalho assinada e os funcionários públicos, que necessariamente são contribuintes. Os autônomos urbanos correspondem a 18,5\% do total de ocupados no Brasil (excluindo-se os menores de 16 anos e os aposentados). Para eles, a previdência social é uma espécie de seguro que protege contra a redução da renda causada pela perda de capacidade laboral em decorrência de doença, velhice etc. A literatura sobre demanda por seguros diz que essa demanda é influenciada pela pelas características socioeconômicas e demográficas das pessoas (idade, gênero, escolaridade, renda, região de residência, entre outros). Assim, este estudo procurou analisar como as características socioeconômicas e demográficas dos trabalhadores autônomos afetam sua escolha entre contribuir ou não para a previdência social. $O$ autônomo toma a decisão de contribuir ou não para previdência social a partir de uma perspectiva de incerteza. Para modelar a opção dos autônomos de contribuir ou não para previdência, utilizou-se neste estudo o modelo Logit e os dados da PNAD de 2013. Dos trabalhadores autônomos urbanos brasileiros maiores de 16 anos, apenas 29\% contribuem para previdência social, e a maioria é do sexo masculino, tem idade entre 40 a 49 anos, possui entre 12 e 15 anos de estudo, reside no sudeste, possui rendimento entre um e dois salários mínimos, atua no comércio e reparação e vive em domicílio com três a quatro componentes. O trabalho autônomo pode ser dividido em dois grupos: o dos autônomos por opção (profissionais liberais); e aqueles que são excluídos do trabalho com carteira assinada (outros autônomos). Dessa maneira, foram estimados dois modelos: um para os profissionais liberais e outro para os outros autônomos. De acordo com os resultados do logit, todos os sinais dos coeficientes do modelo estimado para os profissionais liberais são iguais aos do modelo dos "outros autônomos", porém, relativamente, as chances de contribuição do modelo dos "profissionais liberais", em sua maioria, são maiores. Apenas o resultado da variável idade mostrou que as chances 
de contribuição do profissional liberal crescem menos com a idade do que no caso dos demais trabalhadores autônomos. Conclui-se que o grande desafio da previdência social brasileira é atrair o contingente de não-contribuintes com políticas mais específicas, levando em conta a heterogeneidade do trabalho autônomo. 


\begin{abstract}
RAMALHO, Edimar Emiliano Soares, M.Sc., Universidade Federal de Viçosa, may 2015. Determinants of social security contributions of self-employed workers in Brazil. Adviser: Elvanio Costa de Souza. Co-adviser: Jader Fernandes Cirino.

For the self-employed workers social security contribution is a matter of choice, once one can contribute or not to the pension system. The same does not happen to employees with a formal contract and civil servants, which necessarily are taxpayers. Urban self-employed account for $18.5 \%$ of the total employed in Brazil (excluding those under 16 years and retired). For them, social security is a kind of insurance that protects against the reduction of income caused by the loss of work capacity due to sickness, old age etc. The literature on demand for insurance says this demand is influenced by the socioeconomic and demographic characteristics (age, gender, education, income, region of residence and so forth). Thus, this study sought to examine how the socioeconomic and demographic characteristics of the self-employed workers affect their choices between contributing or not to social security. The self-employed makes the decision to contribute or not for social security from a perspective of uncertainty. To model the option of self-employed to contribute or not for social security system, in this study we used the logit model and the National Household Survey data from 2013. Among the Brazilian urban self-employed workers who are over 16 years old, only $29 \%$ contribute to social security and the majority of them fit in the following characteristics: they are male; they aged 40 to 49 years; they received an average of 12 to 15 years of formal schooling; they afford their families; they live in the southeast region of the country; they earn between one and two times the minimum wage; they work in trade and repair; and live together with other three or four people. Self-employment can be divided into two groups: the self-employed by choice (those who are engaged in liberal professions); and those who are excluded from working with a formal contract (other autonomous) Thus, it was estimated two models: one for professionals and one for other freelancers. According to the results of the logit, all signs of the estimated model coefficients for the self-employed are the same as the model of "other autonomous". However, relatively, the standard contribution chances of "professionals" are mostly bigger. Only the result of the age variable showed that the chances of the liberal professional contribution grow less with age than in the case of
\end{abstract}


other self-employed. It concludes that the great challenge of Brazilian social security system is to attract the non-payers contingent with more specific policies, taking into account the heterogeneity of self-employment. 


\section{INTRODUÇÃO}

\subsection{Considerações Iniciais}

Diante de incertezas e inseguranças a que estão expostos os indivíduos em uma sociedade, sejam elas desemprego, doença, morte, ou mesmo acidentes de trabalho, surgiu a previdência social, cuja finalidade é resguardar as pessoas e garantir-lhes padrões mínimos de sobrevivência, socialmente vistos como dignos (NORONHA, 2005). Assim, dentre as diversas funções da previdência social, a mais básica é funcionar como um mecanismo de proteção coletiva (ou seguro social) contra os riscos enfrentados pelas pessoas (AFONSO, 2003).

Observou-se na Europa o surgimento de dois modelos de proteção social: o modelo bismarckiano (Alemanha, século XIX), que tinha por objetivo garantir aos trabalhadores (e não aos cidadãos em geral) acesso a um seguro social por meio de contribuições pagas em conjunto com o empregador; e o modelo inglês, que surgiu como um sistema alternativo e com uma proposta mais abrangente de contemplar todos os cidadãos (empregados, trabalhadores autônomos, donas de casa, pessoas sem renda, aposentados, cidadãos em idade de trabalhar etc.) com o benefício previdenciário pago pelo Ministério da Fazenda (MELGUIZO; BOSCH;PAGÉS,2013).

No caso do Brasil, amplamente influenciado por estes modelos, tem-se como marco da previdência social a Lei Eloy Chaves (de 1923), que na prática só estendeu aos trabalhadores da iniciativa privada os direitos já concedidos aos servidores públicos (AFONSO, 2003). Inicialmente, o sistema previdenciário brasileiro era caracterizado como de capitalização, de forma que a aposentadoria recebida pelo indivíduo provinha de suas próprias contribuições ao longo da vida ativa. Posteriormente, passou-se para um sistema de repartição (em vigor atualmente) no qual a aposentadoria é financiada pela contribuição dos indivíduos na ativa.

Atualmente, a contribuição ao sistema previdenciário é obrigatória, sendo entendida pela análise do processo de universalização de cobertura que garantiu a parcelas cada vez maiores da sociedade os direitos previdenciários. Por um lado, a obrigatoriedade da contribuição busca evitar o comportamento oportunista (free-rider) ${ }^{1} \mathrm{e}$

\footnotetext{
${ }^{1}$ Usa o bem público sem contribuir para sua provisão (VARIAN, 1992).
} 
por outro, procura diminuir a miopia das pessoas, uma vez que essas podem calcular de maneira incorreta as suas necessidades na velhice (AFONSO, 2003). Contudo, o cenário verificado é de muitos indivíduos contribuindo com um valor menor ou não contribuindo, incentivados pela ineficiência da Justiça e pela falta de uma fiscalização mais rigorosa por parte do Estado (NERI, 2007). Entre os trabalhadores assalariados a contribuição é feita automaticamente, sendo deduzido no momento do repasse dos proventos. Alguns trabalhadores contribuem se acharem necessário, como é o caso dos trabalhadores autônomos, abrindo mão de alguns benefícios, como por exemplo, aposentadoria, salário-maternidade, pensões, entre outros.

A previdência social no Brasil é composta por três regimes: o Regime Geral de Previdência Social (RGPS); o Regime Próprio de Previdência Social (RPPS); e o Regime de Previdência Complementar. (MPS, 2014).

Segundo o Instituto de Pesquisa Econômica Aplicada (IPEA, 2007), são segurados do Regime Geral de Previdência Social: empregados (inclusive domésticos); trabalhadores avulsos (que prestam serviço a várias empresas e são contratados por sindicatos e órgãos gestores de mão-de-obra); contribuintes individuais (pessoas que não têm carteira assinada e que contribuem para a Previdência, tais como autônomos, trabalhadores sem vínculo empregatício que prestam serviços de natureza eventual a empresas, e empregadores); segurados especiais (trabalhadores rurais e pescadores artesanais que exercem suas atividades em regime de economia familiar, sem utilização de mão-de-obra assalariada permanente); e segurados facultativos (pessoas com mais de 16 anos que não têm renda própria e que contribuem para a Previdência Social).

Esse modelo de contribuição não condiz com a realidade dos autônomos, pois a contribuição é obrigatória apenas quando existe relação de emprego. Narita (2013) aponta que $85 \%$ dos autônomos não contribuem para a previdência social no Brasil; $82 \%$ dos autônomos trabalham em seu próprio negócio, sem sócios ou empregados; $75 \%$ trabalham o dia todo; $64 \%$ são do sexo masculino; e $63 \%$ têm menos de nove anos de escolaridade ${ }^{2}$.

Segundo Pastore (2005), o reconhecimento dessa classe trabalhadora implicaria em um novo aparato institucional e um regime próprio de previdência social para que possa atrair os autônomos para o sistema previdenciário.

\footnotetext{
2 Dados extraídos da Pesquisa Mensal de Emprego (PME) e Pesquisa Nacional por Amostra de Domicílios (PNAD) entre 2002 e 2007.
} 
O auto-emprego é fruto de uma estratégia de ocupação. Por um lado, o trabalhador autônomo é uma alternativa ao desemprego, à incapacidade de absorção do setor mais dinâmico da economia e uma forma de atender ao setor industrial e agrário. Por outro, há quem valorize a autonomia por causa da maior flexibilidade do trabalho, chance de montar um próprio negócio e liberdade para fazer outras coisas (MACHADO; OLIVEIRA;ANTIGO, 2008). Por essa razão, para entender a decisão da contribuição dos autônomos como demanda de seguros, eles podem ser divididos em dois grupos: os autônomos por opção; e aqueles que são excluídos do trabalho com carteira assinada. ${ }^{3}$

\subsection{Problema e sua importância}

A previdência social é uma espécie de seguro, uma vez que um seguro pode ser entendido como um produto financeiro que permite a um indivíduo em um cenário de incerteza transferir risco. A demanda por seguro é influenciada pela natureza geral das preferências de risco dos indivíduos, e estas são influenciadas pelas características socioeconômicas desses mesmos indivíduos (LOKE; GOH, 2012). Segundo Afonso e Carvalho (2011), os seguros são ferramentas úteis para gerenciar o risco se duas características são atendidas: a probabilidade de ocorrência do evento indesejável deve ser baixa e a severidade desse evento deve ser elevada. De forma geral, a aquisição do seguro permite que o agente econômico dilua os riscos decorrentes da perda ou da imposição de danos a seus bens ou da redução de sua capacidade de geração de renda.

No Brasil, a previdência social é enquadrada no sistema de seguridade social. Este permite aquele atuar como um programa de pagamentos feitos às pessoas como forma de compensar a incapacidade de trabalho, desemprego involuntário, reclusão ou morte. Os indivíduos que contribuem com parte da sua renda para o seguro social são chamados de "segurados" (MARQUES, 2003).Portanto, a previdência social é caracterizada como uma compra de seguro, no qual as aposentadorias e pensões são financiadas pelas contribuições dos próprios beneficiários(CAMARGO, 2004).

Levando em conta essa linha de raciocínio, a pesquisa ora proposta anseia entender as razões que levam os trabalhadores autônomos a contribuir para previdência social, ou seja, analisar a contribuição voluntária à previdência social como uma demanda por seguros dos trabalhadores autônomos.

\footnotetext{
${ }^{3}$ Classificação utilizada por Machado, Oliveira e Antigo (2008).
} 
Para compreender tal questão, é válido considerar os fatores culturais, históricos e normativos, bem como o grau de heterogeneidade do mercado de trabalho, pois poderão resultar em respostas diferenciadas por parte dos trabalhadores autônomos.

Arias et al (2007) identificaram dois grupos distintos no mercado de trabalho. Para os trabalhadores por conta própria e pequenos proprietários, o processo da informalidade não ocorre devido à exclusão do mercado de trabalho, eles escolhem o setor informal por maiores níveis de satisfação e possibilidade de maior autonomia, bem como maior flexibilidade de horário. Além disso, os autores evidenciaram que esses não se importam com proteção social, isto é, não é interessante contribuir para previdência social. Três motivos desincentivam a contribuição: desinformação da proteção social, arranjos familiares para suprir a proteção social e acesso gratuito de outros programas que fazem parte do sistema de seguridade social (saúde e assistência social). E o outro grupo era formado por empregados domésticos e empregados de microempresas, Arias et al (2007) caracterizaram, em parte, o problema com a renda quanto ao trabalho informal.

Contudo, Machado, Oliveira e Antigo (2008) destacam diferenças no primeiro grupo de Arias et al (2007) para a realidade brasileira. Os trabalhadores autônomos podem ser divididos em dois grupos: os autônomos por opção; e aqueles que são excluídos do mercado de trabalho com carteira assinada. Nessa nova composição, devem-se considerar os trabalhadores autônomos por opção como sendo os profissionais liberais e outros autônomos como vendedores ambulantes, artesões, barbeiros, entre outros.

Os obstáculos que impedem um consenso na definição do trabalhador autônomo são evidenciados pela análise diferente dos autores por causa das diferentes leis em seus países, bem como as transformações significativas na relação de mercado de trabalho. Diversos países procuraram um conceito mais eficaz com o objetivo de disponibilizar um sistema que assegura a cobertura da seguridade social e proteções nos termos da legislação trabalhista para o trabalhador autônomo (PERDESINI; COLLETO, 2010)

Segundo Blanchflower (2000), o trabalho autônomo pode ser considerado como a forma mais simples de empreender, pois dificilmente precisa-se de altos investimentos, conhecimento avançado nas leis e na gestão e maiores explorações nas operações. Apesar de ser uma categoria que tende a ser mais arriscada por causa da vulnerabilidade dos negócios, muitos trabalhadores sentem-se mais satisfeitos com a 
autonomia, com possibilidade de maiores rendimentos e por maior senso de independência (CONSTANT; ZIMMERMANN, 2006).

Stam (2008) considera o trabalho autônomo como um fenômeno de decisão, ou seja, é escolher trabalhar por conta-própria ao invés de trabalhar para terceiros. Esta atividade econômica está ligada a novas ideias, liderança, poder de organização e uma forma de se diferenciar das outras pessoas.

Já Menezes e Cruz (2007) afirmam que o trabalhador por conta própria é um profissional sem necessidade de vínculo empregatício e pode atender aos setores público e privado. Nesse aspecto, o trabalhador autônomo apresenta vantagens sobre trabalhador assalariado, uma vez que as empresas contratantes poderão reduzir seus custos, como por exemplo, com encargo previdenciário.

Observa-se que o trabalhador autônomo tem diferentes definições na literatura. Além disso, não existem estudos que analisam a contribuição voluntária à previdência social como uma demanda por seguros. Assim, o propósito do presente trabalho é analisar os determinantes da contribuição previdenciária dos trabalhadores autônomos no Brasil. Foca-se exclusivamente nos trabalhadores autônomos devido à liberdade que eles têm de participar ou não do sistema previdenciário, o que não ocorre com os empregados com carteira de trabalho assinada e os funcionários públicos, por exemplo. Dito isto, em um contexto que envolve riscos e incertezas, a decisão de contribuir ou não para previdência social faz com que os trabalhadores autônomos sejam diferentes entre si.

Os autônomos urbanos correspondem a 18,5\% do total de ocupados no Brasil, excluindo os menores de 16 anos e aposentados. Desse percentual, cerca de $71 \%$ não contribuem para previdência social, trabalhando principalmente na construção civil e no comércio e reparação (IBGE, 2013).

Deste modo, o presente trabalho poderá ser importante para previdência social e, no geral, para todos os trabalhadores autônomos que não veem necessidade de regularizar suas atividades, pois o estudo consiste mostrar como as características socioeconômicas afetam a escolha dos trabalhadores em contribuir para previdência. Assim, este estudo poderá mostrar para os formuladores de politicas públicas como adotar medidas específicas para atrair os trabalhadores autônomos não-contribuintes. 


\subsection{Objetivo}

\subsubsection{Objetivo Geral}

Este trabalho procura analisar como as características socioeconômicas dos trabalhadores autônomos brasileiros afetam sua decisão de contribuir ou não para a previdência social.

\subsubsection{Objetivos Específicos}

a) Discorrer sobre a história da previdência social e sua relação com o trabalhador autônomo;

b) Analisar como as características socioeconômicas afetam a decisão de contribuir para previdência social dos profissionais liberais e outros trabalhadores autônomos. 


\section{A PREVIDÊNCIA SOCIAL BRASILEIRA}

\subsection{Questões preliminares}

Para compreender os determinantes da contribuição previdenciária dos trabalhadores autônomos é relevante expor o processo de desenvolvimento econômico e histórico da Previdência Social no Brasil, uma vez que podem ser encontradas questões que ajudam a explicar a demanda do trabalhador autônomo frente ao benefício social.

Inicialmente, é necessário elucidar que o sistema de seguridade social é dividido em três segmentos: Previdência Social; Saúde; e Assistência Social. O primeiro é caracterizado por funcionar como um seguro social, assegurando os indivíduos por meio de uma escala contínua de contribuições, as condições necessárias a sua sustentação e a de seus subordinados. Essa contribuição é o preço pago mensalmente para manter o nível de renda, em caso de perda ou redução da capacidade laboral, tal como a velhice, morte e acidentes de trabalho(FIPE, 1993). Desse modo, fica claro, que deve existir um equilíbrio entre as contribuições e os valores recebidos.

Diferentemente da Previdência Social, a Saúde é um sistema que adota todas as medidas necessárias de tratamento e cuidado relacionados com os problemas que afetam o bem-estar físico e mental do individuo. Mesmo se o indivíduo contribuinte não sofrer nenhum tipo de agravo, irá contribuir para outros indivíduos que necessitam dos cuidados médicos (OLIVEIRA; BELTRÃO, 1997).

A Assistência Social pode ser compreendida como uma política que garante o mínimo necessário para condições de uma vida digna de todos os indivíduos, e é dever do Estado julgar quais estão abaixo desse nível. Particularmente, esse sistema enfatiza a distribuição, transferindo renda das classes mais altas para classes mais baixas. Neste sentido, torna-se claro que a relação contribuição efetuada e o valor recebido fica muito estreita, ou mesmo nem existirá, uma vez que o peso do financiamento recai sobre as pessoas com maior poder econômico (AFONSO, 2003).

$\mathrm{Na}$ teoria, esses sistemas sociais deveriam ter planejamentos e objetivos diferentes por causa das suas particularidades (AARON, 1982). No entanto, essas três esferas são agrupadas em um mesmo projeto para muitos países, inclusive no Brasil. 
Na prática, existem vários benefícios oriundos da expansão do Welfare State ${ }^{4}$ que se encontram na fronteira entre a Previdência Social, Saúde e Assistência Social. Por outro lado, a junção destas três áreas leva a um conflito dos recursos existentes (AFONSO, 1999).

Os recursos da previdência social podem ser alocados em dois regimes: sistema de repartição ou sistema de capitalização. No primeiro, a aposentadoria recebida pelos indivíduos provém da contribuição de indivíduos que estão na vida ativa, ou seja, cada geração é financiada na velhice pelas contribuições das gerações seguintes, isso é chamado de solidariedade intergeracional. Segundo Afonso (1999), a forma que é designada esse regime é indeterminada, pois em todos os países que adotam o regime de repartição, a contribuição previdenciária é compulsória. A explicação para isso é dada de duas formas: a sociedade estava preocupada com a velhice e as condições de vida dos idosos, ou então, foi um resultado do contexto econômico e demográfico da sociedade.

A Previdência Social pode ser vista ainda como uma poupança de longo prazo e como um seguro que transforma o consumo presente da vida ativa em consumo futuro durante a aposentadoria (BARR; DIAMOND, 2006). Esse consumo é pago através de uma alíquota determinada pelo Estado. Por consequência, faz-se necessário saber a taxa de retorno desse regime. Conforme Diamond (1965), a taxa de retorno do regime de repartição é igual à taxa de crescimento econômico, uma vez que essa é determinada pela taxa de crescimento dos salários reais e da população. Logo, o valor da aposentadoria é definido pelos fatores econômicos, demográficos e tecnológicos, responsáveis pelo aumento dos salários.

No regime de capitalização, o valor da aposentadoria recebido pelo individuo é todo o montante financiado pelo próprio indivíduo ao longo da sua vida ativa. Todo o valor poupado é capitalizado e aplicado. A taxa de retorno desse regime é medida pela taxa de juros vigente do mercado. Como nesse regime cada um é responsável pela sua aposentadoria, a solidariedade intergeracional compulsória não existe.

Ainda que possa parecer simples contribuir para a Previdência Social, essa tarefa, em termos práticos, é muito complicada, uma vez que as pessoas encontram vários empecilhos ao longo da vida que atrapalham a acumulação em nível ótimo de poupança de longo prazo, tais como as incertezas, ausência de informação, fatores

\footnotetext{
${ }^{4}$ Estado de bem-estar social, onde é dever do estado atuar como regulamentador do sistema social e econômico.
} 
psicológicos e condições socioeconômicas. Esse último ultrapassa as dificuldades inerentes da transferência de consumo presente para futuro, pois algumas regiões ou países sofrem com o problema de baixo nível de renda salarial, tornando mais fraca a decisão de poupar. $\mathrm{O}$ alto custo de oportunidade que tem cada centavo para necessidades imediatas tem valor mais significativo (MELGUIZO; BOSCH; PAGÉS, 2013).

Nessa direção é que faz sentido a obrigatoriedade da contribuição, mesmo que sejam atribuídas diferentes taxas de contribuição para diferentes segmentos sociais. Muito vezes, quando as pessoas não conseguem calcular o quanto é necessário para o consumo presente e futuro, a alocação intertemporal do consumo é insuficiente em relação às necessidades da velhice. Tal problema é chamado de miopia dos agentes ${ }^{5}$. Outro problema que envolve a obrigatoriedade da contribuição é a racionalidade limitada, pois os indivíduos são incapazes de compreender e dominar o tempo. Além disso, a falta de informação faz com que os indivíduos entendam de maneira incorreta a complexidade do sistema previdenciário, direcionando as escolhas inadequadas de consumo e poupança.

Segundo Veal (1986), é importante a obrigação da contribuição para a previdência, pois isso permite diminuir o problema com free-riders. Vários indivíduos deixariam de contribuir para Previdência Social se soubessem que o Estado, através da parte assistencialista, os sustentaria no caso de não terem renda suficiente na velhice. Obviamente, se todos os indivíduos adotassem esse comportamento o processo se tornaria inviável. No entanto essa alegação é válida para inferir sobre a capacidade e racionalidade dos indivíduos. A Figura 1 resume o desenho da Seguridade Social no Brasil, evidenciando seus sistemas, como é dividido a previdência social e os problemas da poupança de longo prazo que essa tem com relação ao trabalhador.

\footnotetext{
${ }^{5}$ Os indivíduos não conseguem enxergar o quanto precisarão poupar ao longo da vida.
} 


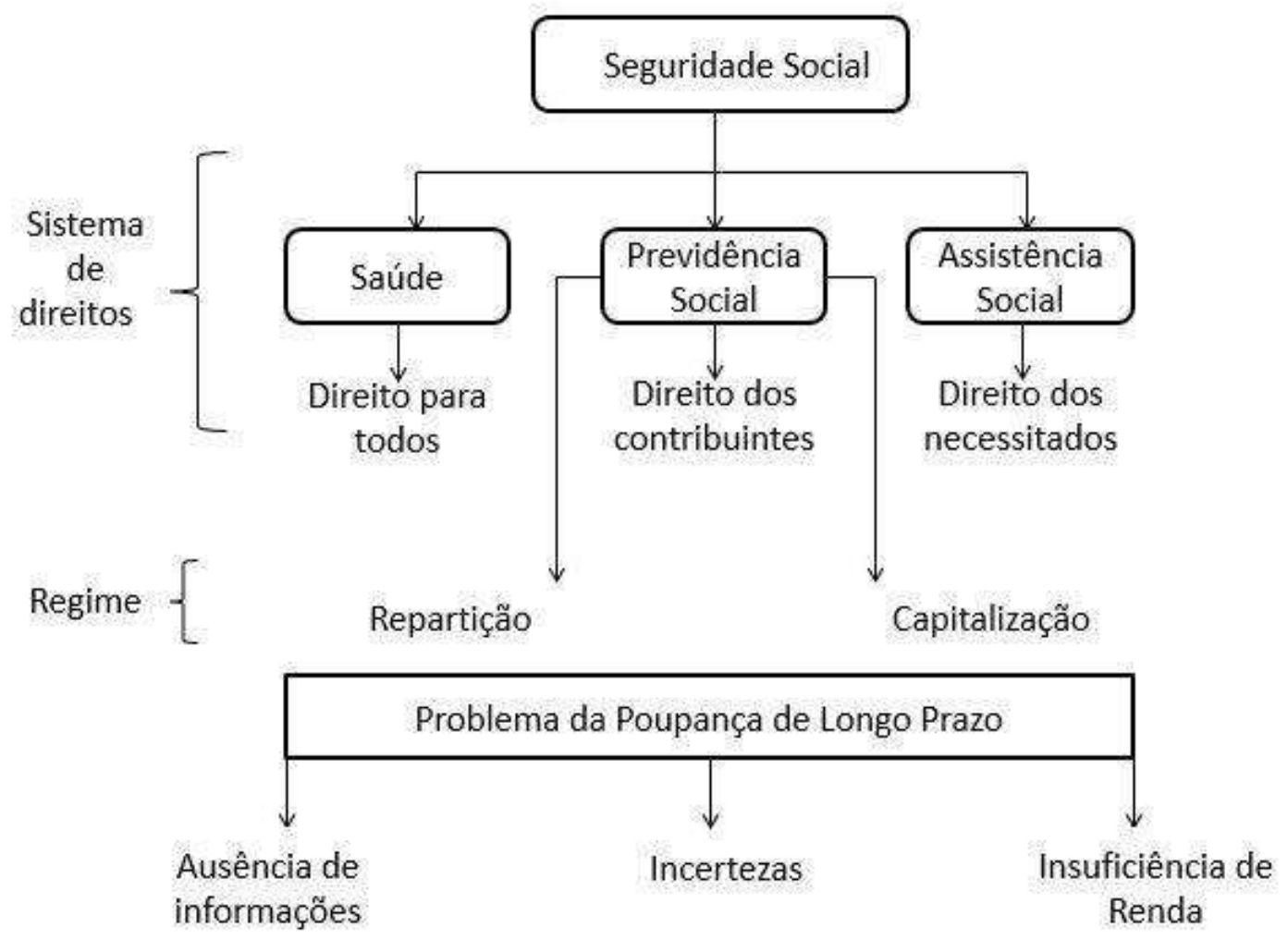

Figura 1 - Quadro analítico do Sistema previdenciário

Fonte: Elaborado pelo o autor com base em Melguizo; Bosch, Pagés (2013).

Embora a contribuição previdenciária no Brasil seja obrigatória para todos os trabalhadores assalariados, uma vez que a contribuição é feita automaticamente, sendo deduzido no momento do repasse dos proventos, grande parte dos autônomos não faz questão de contribuir para previdência social. Segundo os dados do IBGE (2013),os autônomos correspondem a 18,5\% do total de ocupados no Brasil. Desse percentual, cerca de 95\% não contribuem para previdência social e nem para previdência privada, trabalhando principalmente na construção civil e no comércio e reparação.

\subsection{A composição da Previdência Social}

A priori, os pontos abordados na primeira seção fornecem uma visão geral de como é a previdência social. Do ponto de vista econômico, a previdência social é uma organização com aspectos tanto microeconômicos quanto macroeconômicos. Segundo Afonso(1999),ela funciona como uma estrutura de poupança de longo prazo, impactando nas decisões e no bem-estar dos indivíduos (visão micro). É também uma 
entidade com grande movimentação de recursos, representando taxas consideráveis do Produto Interno Bruto (PIB) em muitos países (visão macro).

A ideia inicial da previdência era cobrir apenas os trabalhadores que possuíam uma relação de dependência com empregador. Dessa maneira, muitas pessoas ficavam excluídas do sistema previdenciário, como por exemplo, os trabalhadores nãoassalariados, grande parte das mulheres, os trabalhadores por conta própria, dentre outros. A opção que sobrava para esses grupos era a ajuda familiar ou alguma renda advinda dos programas sociais.

Devido a esse formato e aos problemas fiscais em termos de sustentabilidade e desigualdade, muitos países modificaram o sistema previdenciário, adotando um sistema múltiplo, administrado pelos setores público e privado (MELGUIZO; BOSH;; PAGÉS, 2013).

Conforme apontado por Hujo (2009), vários países latino-americanos implementaram um sistema previdenciário compulsório de capitalização. No ano de 1981, o Chile foi o primeiro país a adotar essa medida (implantou um sistema previdenciário gerenciado por fundos de pensão privados). No regime chileno, os trabalhadores com vínculo empregatício e funcionários públicos contribuíam com uma taxa obrigatória em troca do benefício da aposentadoria ao final da vida ativa.

Além do Chile, outros países latino-americanos que implementaram a reforma foram: Peru, em 1993; Colômbia, em 1994; Argentina, em 1994 (com uma nova reforma em 2008); Uruguai, em 1996; Bolívia e México, em 1997; El Salvador, em 1998; Costa Rica e Nicarágua, em 2000; e República Dominicana, em 2003.

Os demais países latino-americanos implementaram um modelo de seguridade social de repartição, cujo financiamento não depende de reservas pré-existentes e os trabalhadores inativos são custeados pelos trabalhadores ativos. Contudo, os obstáculos ligados ao envelhecimento populacional impedem uma distribuição mais eficiente, uma vez que o número de indivíduos inativos pode ser maior que o número de indivíduos ativos.

A previdência social no Brasil é composta por três regimes: o Regime Geral da Previdência Social (RGPS) e o Regime Próprio de Previdência Social (RPPS), que são regimes de repartição, e o Regime de Previdência Complementar, que é um regime de capitalização. Os dois primeiros são obrigatórios e administrados por órgãos públicos. $\mathrm{O}$ terceiro é facultativo e garante proteção adicional para o contribuinte (REIS, 2012). 
O RGPS é destinado aos trabalhadores do setor privado, sendo financiado por arrecadação dos empregadores, empregados e as transferências da União, geralmente provenientes das contribuições sociais, tais como a Contribuição Social sobre o Lucro Líquido (CSLL), a Contribuição para o Financiamento da Seguridade Social (COFINS) e a Contribuição Provisória sobre a Movimentação ou Transmissão de Valores e de Créditos e Direitos de Natureza Financeira (CPMF).

O RPPS é destinado aos servidores públicos de cargo efetivo da União, dos Estados, do Distrito Federal e é financiado pela contribuição desses mesmos servidores. O Regime de Previdência Complementar é operado por entidades abertas e fechadas de previdência complementar. Seu principal objetivo é estabelecer planos privados de renda, passando a noção de complementariedade para os outros dois regimes, por meio da contribuição de seus participantes (PINHEIRO, 2007).

\subsection{Previdência social e mercado de trabalho}

A previdência social do Brasil surgiu sob influência do modelo de seguridade social bismarckiano fundado na Alemanha no fim do século XIX, mais precisamente no ano de 1883. Esse modelo transmite a ideia de que os trabalhadores assalariados seriam, exclusivamente por meio de contribuições, protegidos socialmente pelo o sistema. $\mathrm{O}$ objetivo era gerar renda adequada na terceira idade para a classe subordinada ao regime, isto é, quem recebia o benefício social eram apenas os trabalhadores com vínculo empregatício, excluindo os trabalhadores não-remunerados, autônomos, empregados domésticos, entre outros. Segundo Melguizo et al(2013), a razão da existência de um instituto que regula o consumo futuro e presente era que o trabalhador se sentia inseguro com seu tempo de vida, pois não tem nada que assegure sua existência, isto é, não tem certeza de que sempre estará saudável e espera um dia ficar muito velho, sem condições de conseguir trabalhar.

Tal modelo bismarkiano é caracterizado como um sistema de seguros sociais, pois esse está muito próximo dos seguros privados. No que tange aos direitos, a cobertura é exclusiva para trabalhadores, o acesso é dependente da contribuição direta anterior e o conjunto das prestações é proporcional à contribuição efetuada. Em relação ao financiamento, os recursos são requeridos da contribuição direta dos trabalhadores. 
No que se refere à administração, o Estado gere em Caixas de previdência os benefícios, tendo a participação dos contribuintes (BOSCHETTI, 2003).

As medidas e políticas desse sistema foram tomada sem função de três motivos. Primeiro, obteve êxito nos países europeus. Em segundo lugar, era difícil para os governos promover benefícios e arrecadar impostos, tornando inexequível a implementação de um modelo que assegurasse a cobertura universal. E por fim, era esperado que houvesse uma redistribuição de renda na transferência de recursos de patrões para empregados (KAPLAN; LEVY, 2014).

Anos depois, em uma conjuntura econômica e política totalmente diferente, surgiu na Inglaterra o Plano Beveridge em 1942, o qual apresenta muitas críticas ao modelo bismarkiano e propõe a instituição do Welfare State. Esse sistema procura atender todas as camadas sociais, assegurando o mínimo social em condições de necessidades, possuindo, dessa forma, um caráter mais universal (BOSCHETTI, 2009). O Plano Beveridge se propôs a

contemplar todos os cidadãos sem nenhum limite superior de renda, porém reconhecendo os diversos meios de vida [...]: i) empregados, ou seja, pessoas cuja ocupação habitual está sob um contrato de serviços; ii) outros ocupados, categoria que inclui empregadores, comerciantes e trabalhadores autônomos de todo tipo; iii) donas de casa, isto é, mulheres casadas em idade de trabalhar; iv) outros ocupados sem renda; v) indivíduos com idade de trabalhar, vi) aposentados [...]. As seis classes de cidadãos receberiam uma aposentadoria [...] paga pelo Ministério da Fazenda (BEVERIDGE, 1943).

A principal diferença dos dois modelos é que o Sistema Beveridgiano tinha como objetivo o combate à pobreza e o Sistema Bismarkiano era para cobrir os riscos sociais dos trabalhadores em condições adversas, mantendo assim a renda (BEVERIDGE, 1943).

Esses modelos influenciaram vários países e gradativamente foram se expandindo com a inclusão dos trabalhadores autônomos, empregados não-remunerados e empregados domésticos. No caso brasileiro, a contribuição previdenciária tornou-se obrigatória para os trabalhadores assalariados. Contudo, muitos trabalhadores assalariados não contribuem em função da ineficiência da Justiça e pela ausência de fiscalização do Estado.

Esse quadro pelo qual o sistema de previdência social foi desenvolvido no Brasil acabou se tornando problemático. Segundo Melguizo, Bosch e Pagés (2013) há pelo menos duas razões: grande parte dos empregados não tem carteira de trabalho assinada e estudos recentes evidenciam que alguns trabalhadores transitam do trabalho com 
carteira assinada para o trabalho sem carteira assinada ao longo do tempo. Muito vezes, essa mobilidade gera consequências graves, afetando o equilíbrio das contribuições previdenciárias, uma vez que esses trabalhadores não se sentem obrigados a contribuir para Previdência Social. O autor conclui que um sistema planejado para fornecer renda no futuro para as pessoas não pode ser universal. Mesmo sendo perfeito o funcionamento do sistema, alguns grupos ficariam excluídos da aposentadoria por não ter vínculo com o mercado de trabalho.

Boschetti (2006) considera o quadro brasileiro de Seguridade Social dividido da seguinte maneira: as ideias relacionadas ao sistema bismarkiano estão próximas da Previdência Social e as ideias do modelo beveridgiano associam-se aos sistemas de saúde e assistencial social.

\subsection{História da Previdência Social no Brasil}

\subsubsection{Primeira década da Previdência Social no Brasil e criação da Lei Eloy Chaves (1920-1928)}

O Sistema Previdenciário Brasileiro inicia-se, legalmente, em 1923. Contudo, entidades responsáveis por questões sociais surgiram séculos antes. Segundo o Relatório da Escola de Pós-Graduação em Economia da Fundação Getúlio Vargas EPGE/FGV(2002), no começo do período colonial já havia entidades com o caráter assistencialista, como por exemplo a Irmandade da Santa Casa de Misericórdia de Santos, fundada em 1543. Em 10 de Janeiro de 1835 foi criado o Montepio Geral de Economia dos Servidores do Estado (MONGERAL), a primeira iniciativa oficial de estabelecer uma sociedade de seguros no país. Os segurados da MONGERAL eram os funcionários do Ministério da Economia. Por meio de contribuições, eram proporcionados benefícios de ordem previdenciária (FARO, 1992).

A expansão das entidades previdenciárias se deu rapidamente no final do século XIX, cuja administração e funcionamento eram dirigidos por empresas e organizações ligadas ao governo. O sistema era financiado por contribuições dos empregados e os benefícios eram compostos pela assistência médica e auxílio em caso de desemprego, invalidez ou morte. Dessa forma, começou a construir alguns mecanismos e amparos a grupos de funcionários públicos através do Estado e mediante uma legislação especifica. 
Em março de 1888 criou-se a aposentadoria dos funcionários dos Correios e foram instituídas Caixas de Socorros nas estradas de ferro. Em 1889 foi estabelecido o Fundo de Pensões dos trabalhadores da Imprensa Nacional. No ano seguinte, surgiram o plano previdenciário dos funcionários da Central do Brasil e do Ministério da Fazenda. Em1892, os operários do Arsenal da Marinha do Rio de Janeiro foram cobertos com o benefício de se aposentar por invalidez e pensão por morte. No inicio do outro século, em 1911, é criada a Caixa de Pensões da Casa da Moeda e em 1912 os beneficiados são os funcionários da Alfândega do Rio de Janeiro.

A criação dessas entidades e organizações foi o primeiro passo para instituir a Previdência Social no Brasil através da Lei Eloy Chaves de 24 de Janeiro de 1923 e com a implantação das Caixas de Aposentadoria e Pensões (CAPs). Essa lei foi aprovada para conceder pensões e benefícios de saúde para trabalhadores ferroviários por meio das CAPs, cuja sede era na própria empresa ferroviária. Mais especificamente, há quatro tipos de benefícios: aposentadorias (normal ou por invalidez), assistência médica ao segurado e seus dependentes, remédios mais baratos e pensão aos dependentes em caso de morte. Para obter os benefícios da aposentadoria, o trabalhador deveria ter completado pelo menos 50 anos de idade e 30 anos de serviço.

Segundo Afonso (2003), é possível observar de início três características do surgimento da Previdência Social: restrito, não-focado e generoso. Restrito pelo número de contemplados (somente os ferroviários são beneficiários).Não-focado por oferecer outros benefícios como saúde e assistencialista. Por fim, generoso, pois gera aposentadorias por invalidez e pensões.

Oliveira e Beltrão (2001) afirmam que a maioria dos países latino-americanos começou o plano previdenciário com seguros destinados a certos grupos, como por exemplo, os servidores públicos, militares entre outros. Durante a maior parte da década de 1920, o sistema evoluiu fragmentado, baseado na baixa cobertura de um conjunto de programas isolados, operando sob regime de capitalização.

Em relação ao financiamento, os empregados contribuíam com 3\% dos salários e o dono da empresa com um valor correspondente a $1 \%$ da receita bruta, além das alíquotas repassadas para as pessoas no consumo. A aposentadoria era calculada conforme o salário dos últimos cincos anos de serviço.

As Caixas de Aposentadorias e Pensões (CAPs), sob o regime de capitalização, eram comandas por um grupo de trabalhadores e donos de empresas, sem intervenção estatal. Cada CAP possuía um número pequeno de sócios que se espalhavam em várias 
organizações. Com o objetivo de regular as questões trabalhistas com a previdência social foi criado o Conselho Nacional do Trabalho em abril de 1923. Contudo, havia poucas pessoas cobertas proporcionalmente ao número total da população.

Em 1926, a Lei n 5.109 aumentou o Regime da Lei Eloy Chaves, passando a ter direto os portuários e marítimos. Houve também ampliação dos benefícios, tal como auxilio-funeral, auxílio serviço-militar, redução de prazos de carências, eliminação da idade mínima para aposentadoria e estabilidade no emprego após 10 anos. No que tange às contribuições, mudanças também foram feitas. As empresas passaram a pagar com $1,5 \%$ da sua receita bruta anual e o repasse das parcelas dos consumidores foi para $2 \%$ do valor das tarifas. Dois anos depois, foi lançada a Lei $\mathrm{n}^{\circ} 5.485$, em que os trabalhadores dos serviços telegráficos e radiotelegráficos foram incluídos no sistema dos seguros.

De acordo com Medeiros (2001), as políticas sociais surgidas antes de 1930 eram fragmentadas e emergenciais. As discrepâncias entre capital e trabalho eram chefiadas por leis que não eram claras e eram basicamente atendidas por aparato policial. O Estado não tinha um programa de saúde pública ativo que garantisse o bemestar social dos cidadãos. Essas questões eram atendidas e resolvidas fundamentalmente pelas autoridades regionais. Em relação à educação, o atendimento era restrito ao grupo acadêmico e elitista, visando formar alunos para o curso superior. Fundação de Economia e Estatística (1983) afirma que a previdência era predominantemente privada, pois era administrada por empresas e categorias profissionais, e os assuntos sobre habitação não faziam parte do escopo da política pública.

\subsubsection{Mudanças no sistema, Governo Vargas e a Crise (1930-1988)}

O Governo Vargas, juntamente com a crise de 1929 e a urbanização, trouxeram um novo retrato para o sistema previdenciário brasileiro. Tal governo ampliou o sistema com a criação dos Institutos de Aposentadorias e Pensões (IAPs). A crise 1929 enfraqueceu e dificultou a produção cafeeira e a urbanização permitiu maior força para trabalhadores assalariados no cenário político-econômico. Nesse novo contexto, o Estado passa a dar mais atenção para os assalariados e, consequentemente, preocupa-se com o seu seguro social e bem-estar. 
O objetivo central dos IAPs era tirar o vínculo direto da previdência com as empresas, passando a ser, em âmbito nacional, ligado à categoria profissional ou categorias relacionadas. Essa nova configuração permitiu uma maior abrangência da cobertura previdenciária, chegando a atingir os trabalhadores autônomos urbanos e grande parte dos assalariados. O Estado criou o Ministério do Trabalho, Indústria e Comércio (MTIC), através do decreto $\mathrm{n}^{\circ}$ 19.433, em novembro de 1930, para regulamentar e fiscalizar o funcionamento do sistema previdenciário. A criação do Ministério da Educação e Saúde Pública foi muito importante para a saúde coletiva da população, no entanto, a atenção médica era somente para os trabalhadores vinculados a categorias profissionais (PASINATO, 2009).

Em 1931, o decreto $n^{\circ} 20.465$ modificou o Regime da Lei Eloy Chaves, incluindo os empregados dos demais serviços públicos, além de fazer algumas mudanças em relação às Caixas de Aposentadorias e Pensões com o intuito de diminuir os gastos com assistência médica e serviços complementares a 8\% das receitas (REIS, 2012).

A década de 1930 trouxe grandes mudanças para o cenário previdenciário brasileiro. Além de ter apresentado alterações na Lei Eloy Chaves, o Governo Vargas criou o Instituto de Aposentadorias e Pensões dos Comerciários (IAPC), a Caixa de Aposentadorias e Pensões dos Trabalhadores em Trapiches e Armazéns de Café e a Caixa de Aposentadorias e Pensões dos Operários Estivadores, Instituto de Previdência e Assistência dos Servidores do Estado (IPASE) e o Instituto de Aposentadorias e Pensões dos Empregados em Transportes de Cargas (IAPETEC).

$\mathrm{Na}$ década seguinte, em 1943, um fato relevante que ocorreu foi a implementação da Lei $n^{\circ}$ 5.452, que criou a Consolidação das Leis do Trabalho (CLT), que tinha como função regulamentar, entre outras coisas, a legislação da Previdência Social. Além de ter como foco a normatização das relações de trabalho e proteção dos trabalhadores, a CLT cria também alguns direitos trabalhistas, tais como a jornada de trabalho de oito horas diárias, período de descanso, férias e insalubridade (PASINATO, 2009).

Ainda que no período governado por Vargas (1930-1945) houve uma participação mais efetiva do Estado no sistema previdenciário e uma ampliação das categorias beneficiadas, é evidente que os benefícios da Previdência Social eram direcionados apenas uma camada da sociedade, como os funcionários públicos e os operários ferroviários. Outro fato notável dessa época é a constante desigualdade 
intragrupos dos beneficiados, pois tanto a CAP quanto a IAP podiam instituir seus próprios pacotes de benefícios e alíquotas de contribuição (REIS, 2012).

Como se percebe, houve várias mudanças nesse novo cenário previdenciário, principalmente, por causa da cobertura heterogênea e da política de regulação. Simultaneamente, houve também alterações no quadro financeiro do sistema: a alíquota de contribuições dos empregados aumentou para 4\% do salário, podendo chegar até $8 \%$.

Depois da Era Vargas, o sistema previdenciário passa a ser caracterizado por crises financeiras nas IAPs, aumento da intervenção estatal e início do direcionamento a caminho da unificação.

No que se refere às IAPs, pode-se dizer que existem dois motivos para sua desestabilização econômica. Em primeiro lugar, a elevação dos gastos assistenciais e a facilidade de acesso aos benefícios fizeram com que o montante das despesas se tornasse maior que o montante das receitas, gerando prejuízo. Segundo os dados apresentados por Oliveira e Teixeira (1986), o valor real anual das receitas cresceu 9,37\% e o das despesas 13,67\% no período 1945-1966. Em segundo lugar, a ausência de um sistema financeiro organizado e responsável para manter o regime previdenciário de capitalização ajudou a agravar o problema. Isso evidencia o descuido da previdência brasileira com as contas públicas, que por sinal se repetiria por mais vezes (AFONSO, 2003).

Dentro desse período (1945-1966), no qual o Estado se deparava com as inconformidades das dívidas com a previdência e o ambiente macroeconômico desfavorável (inflação elevada e a lei da usura $^{6}$ ), houve a necessidade imediata de mudança de regime, do sistema de capitalização para o de repartição.

Em razão do maior poder do Estado, nessa época, foram criados o Conselho Superior e o Departamento Nacional de Previdência Social, cujas funções eram normatizar e controlar o sistema previdenciário.

Por último, houve a tentativa de unificação da previdência social, por meio do decreto $\mathrm{n}^{\circ}$ 7.526, em 1945, que liberou a criação do Instituto de Serviços Sociais do Brasil (ISSB). Tal organização transmitia a ideia de avanço para o Brasil, pois deixava de lado a classificação das categorias profissionais de grupos diferentes e incluía todos os brasileiros e estrangeiros que possuíam algum tipo de rendimento, ou seja, além de unificar o sistema, o projeto tinha como proposta a universalização da previdência

\footnotetext{
${ }^{6}$ Lei que limitou a taxa de juros em $6 \%$ ao ano, evitando cobranças abusivas de juros.
} 
social. Porém, tais procedimentos não foram possíveis devido ao afastamento de Getúlio Vargas. Apenas em 1960, com a Lei Orgânica da Previdência Social (LOPS), foi iniciada a unificação e consolidada em 1966 da previdência social. Mais uma vez o campo previdenciário se manifesta resistente a mudanças, pois existem várias dificuldades para discussão do assunto no legislativo. Entre elas estão a perda de privilégios e interesses de alguns grupos (AFONSO, 2003).

Essa Lei foi um importante marco estabelecido com intuito de uniformizar e unificar a previdência e estreitar a diferença existente entre as categorias profissionais. No ano de 1960, durante o período de tramitação da unificação, a LOPS foi instituída por meio do decreto $\mathrm{n}^{\circ} 3.807$. Vários anos de tentativa de busca que foram alcançados somente nesse ano.

No plano substancial, a Lei Orgânica da Previdência Social (LOPS) ampliou os benefícios acrescentando auxílio natalidade, auxílio funeral e auxílio reclusão e estendeu a assistência para as demais categorias profissionais, além de definir os benefícios como a média dos salários dos últimos 12 meses de contribuição. Os trabalhadores autônomos, profissionais liberais e empregados urbanos foram incluídos como segurados do sistema, e fixou-se a alíquota de contribuição entre $6 \%$ e $8 \%$. O Estado ficou responsável pelo pagamento de pessoal e dos encargos sociais referentes à gestão previdenciária e à cobertura de uma eventual falta de renda.

A LOPS foi um grande passo para a universalização do sistema previdenciário. Contudo, foram deixadas lacunas para preencher. Primeiro, os trabalhadores rurais não foram contemplados com as novas normas. Delgado e Cardoso (2000) afirmam que um dos principais motivos para a legislação trabalhista não incluir o restante das categorias dos trabalhadores foi a falta de poder político e econômico dessas classes. Desse modo, os trabalhadores rurais usufruíram dos benefícios previdenciários apenas no penúltimo ano do governo João Goulart. Na teoria, os trabalhadores autônomos, profissionais liberais e empregados foram cobertos pela previdência, entretanto, na prática, menos de $10 \%$ dos trabalhadores autônomos e profissionais liberais e cerca de $50 \%$ dos empregados urbanos eram cobertos pelo sistema (OLIVEIRA; BELTRÃO, 2001).

Em 1963 foi editada a lei $\mathrm{n}^{\circ} 4.214$, que criou o Fundo de Assistência ao Trabalhador Rural (FUNRURAL), estendendo alguns benefícios alcançados pelos trabalhadores urbanos para os trabalhadores rurais. Dois anos mais tarde houve alteração na emenda constitucional, inibindo a concessão de direitos previdenciários àqueles que não obedeciam a lei em sua devida forma de custeio. Tal ação tinha como 
objetivo eliminar a concessão irresponsável dos benefícios, principalmente aos políticos.

No ano de 1965 foram criados o Fundo de Garantia por Tempo de Serviço (FGTS) e o Instituto Nacional de Previdência Social (INPS), que agrupou os seis institutos de aposentadorias e pensões existentes, assim concretizando a unificação da previdência social brasileira. $^{7}$

A união dos institutos foi uma medida vantajosa para agregar o custeio da previdência. Esse novo molde permitiu maior equilíbrio nas contas, uma vez que o superávit de alguns institutos foi usado para cobertura do déficit de outros. Outra vantagem foi a perda total das funções gerenciais das empresas e trabalhadores sobre o controle da previdência, que passou a ser dirigido totalmente pelo governo militar e, dessa forma, gerou redução de custos previdenciários.

Com um sistema previdenciário mais amplo, em 1974 foi criado o Ministério da Previdência Social e Assistência Social (MPAS) através da lei $n^{\circ} 6.036$. Esse órgão foi separado do Ministério do Trabalho e Previdência Social para exercer a função de elaboração e aplicação de políticas de previdência e assistência médica e social.

É nessa época que foi criado o subsídio para pessoas necessitadas acima de 70 anos. O plano assistencial atendia os trabalhadores urbanos, rurais e deficientes, oferecendo um auxílio pecuniário equivalente à metade de um salário mínimo.

Em 1977, com a criação do Sistema Nacional de Previdência Social (SINPAS), ocorreu uma nova formação da estrutura institucional, tornando-se um processo de especialização funcional, em que novas autarquias foram criadas e outras foram redefinidas. As instituições anteriores (INPS e FUNRURAL) ficaram dispostas da seguinte forma:

a) INPS: ficou incumbido apenas pelos pagamentos dos benefícios e reabilitação profissional dos trabalhadores rurais e urbanos;

b) Instituto Nacional de Assistência Médica da Previdência Social (INAMPS): foi criado para prestar serviços de saúde a todos os segurados;

c) Instituto de Administração Financeira da Previdência e Assistência Social (IAPAS): tinha como função gerir a parte financeira, patrimonial e administrativa da previdência;

\footnotetext{
${ }^{7}$ O INPS é o atualmente denominado Instituto Nacional de Seguro Social (INSS), que cuida do Regime Geral de Previdência Social (RGPS), que assegura os trabalhadores do setor privado.
} 
d) Legião Brasileira de Assistência (LBA)e Fundação Nacional do Bem-Estar do Menor (FUNABEM): responsáveis pelos serviços assistenciais para pessoas carentes e jovens criminosos e abandonados;

e) Dados da Previdência Social (DATAPREV): agencia de apoio para processamento de dados de autarquias; e

f) Central de Medicamentos (CEME): tomava conta da distribuição de medicamentos mais baratos ou a preço de custo.

Além dessas mudanças estabelecidas no regime do sistema público, o Estado também determinou algumas mudanças na previdência privada. Essas alterações surgiram depois de várias falhas nos planos particulares de pensões, geridos por instituições com fins lucrativos. No mesmo ano foi criada a lei $\mathrm{n}^{\mathrm{o}} 6.435$ para regulamentar o regime privado da previdência. Fortemente influenciado pelo modelo americano Employee Retirement Income Security Acty (ERISA), esta lei define as condutas necessárias para o bom funcionamento da rede previdenciária privada, separando as instituições em dois grupos: ${ }^{8}$

a) Instituições abertas, sendo supervisionadas por empresas financeiras e de seguros; e

b) Instituições fechadas, geridas por uma ou mais empresas e coordenadas pela autarquia Ministério da Previdência e Assistência Social (MPAS).

A lei restringia estas instituições a operar apenas pelo regime de capitalização, além de instituir várias regras para diversificação da carteira, responsabilidades fiduciárias, multas aos administradores não confiáveis, dentre outras coisas.

A composição da estrutura previdenciária ficou dividida em dois sistemas compulsórios e um facultativo. Os sistemas compostos pela contribuição obrigatória são formados pelo INPS, responsável pelos trabalhadores da rede privada, e outro sistema que cobria os funcionários públicos federais e estaduais. ${ }^{9} \mathrm{O}$ sistema facultativo é a atual previdência privada.

Com o sistema reformulado, a cobertura da Previdência Social brasileira chegava a cerca de $50 \%$ da população economicamente ativa, porém com muitos direitos diferentes, volume de gasto por volta de 5\% do PIB e as contas financeiras estavam mantidas em plena harmonia com equilíbrio fiscal (DRAÍBE, 1993).

\footnotetext{
${ }^{8}$ A lei federal ERISA foi estabelecida nos Estados Unidos para assegurar padrões mínimos nos planos de pensões e de saúde.

${ }^{9}$ Esse sistema foi instituído em 1990 pela lei nº 8112 para regular os servidores públicos, denominado Regime Jurídico Único (RJU).
} 
Entretanto, no início da década de 1980 houve uma crise no INPS devido ao aumento dos gastos da previdência social sem qualquer tipo de planejamento visando à eficiência, modernização tecnológica e implementação de novos procedimentos (SILVA; MÉDICI, 1991). Segundo Ferreira e Souza (2008), a previdência social foi influenciada por condições econômicas adversas, como por exemplo, a crise financeira internacional, pressão política por medidas redistributivas e ajustes recessivos. Além disso, a produção industrial do país passava por uma redução de $10,4 \%$, provocando uma queda no PIB de 3,1\% (ABREU, 1989).

Afonso (2003) argumenta que os obstáculos que o INPS apresentou naquela época estão relacionados a fatores estruturais, que envolvem a disparidade entre a expansão dos benefícios e as fontes de financiamento, e à conjuntura econômica (aumento da inflação, queda na taxa de crescimento da economia). Para contornar esse quadro, o governo toma algumas medidas com o objetivo de equilibrar as contas públicas mediante o aumento das receitas.

\subsubsection{Em direção à universalização e reformas}

Passados 20 anos de regime militar, a Constituição Federal de 1988 foi promulgada, dando novos passos à Previdência Social no que tange às questões sociais, uma vez que existe uma preocupação em assegurar a toda população um conjunto de direitos sociais. Baseando-se no conceito de Seguridade Social foram estabelecidos como princípios básicos a universalização da cobertura e atendimento, a uniformidade e equivalência de benefícios urbanos e rurais, a seletividade e distributividade na concessão dos benefícios e serviços, o caráter democrático dos subsistemas (previdência, saúde e assistência social), a irredutibilidade do valor dos benefícios, os princípios de equidade na forma de participação no custeio, a diversificação da base de financiamento e a descentralização e participação de trabalhadores, empresários e beneficiários na gestão (BRASIL, 1988).

Dessa forma, em termos de seguridade social, houve um grande avanço rumo à universalização, tanto para Instituto Nacional de Previdência Social (INPS), quanto para o sistema dos funcionários públicos.

Oliveira e Beltrão (2001) relatam alguns fatores que ajudaram na universalização. No que se refere ao INPS, inúmeras regras foram agregadas na nova 
Constituição a fim de proteger os trabalhadores da rede privada contra eventuais violações dos direitos. São elas:

a) Incorporação do Conceito da Seguridade Social, definido como um conjunto de três subsistemas (previdência, saúde e assistência social);

b) Criação de uma unidade financeira, financiada pelas contribuições advindas dos salários, receitas brutas, lucros das empresas, dentre outras;

c) Garantia de direito à saúde a todo cidadão;

d) Duplicação dos valores de assistência social e de segurança social rural;

e) Diminuição de cinco anos do limite de idade para aposentadorias rurais;

f) Recontagem dos valores dos benefícios para recompor seu valor original;

g) Indexação dos salários e valores dos benefícios à inflação; e

h) Piso de um salário mínimo para todos beneficiários.

Em relação aos servidores públicos, a Constituição de 1988 ajustava as diferenças entre as formas de contratos de funcionalismo público existentes no Brasil desde 1964.

Em 1990, a lei $\mathrm{n}^{\circ} 8112$ incorporou todos os funcionários públicos dentro do Regime Jurídico Único (RJU). ${ }^{10}$ As principais peculiaridades deste regime são: plena estabilidade no emprego; benefícios iguais ao ultimo vencimento; e associação do valor dos benefícios com o salário do pessoal ativo. Nesse novo molde, muitos funcionários públicos deixaram de contribuir para o INPS e começaram participar do RJU. A contribuição desse último também é descontada no momento do repasse dos proventos.

Segundo Neri (2007), a Constituição de 1988 gerou vários benefícios sem se preocupar com as fontes de financiamento, implicando em desequilíbrio nas contas do sistema previdenciário brasileiro. Além disto, mudou os incentivos na decisão de participar da previdência ao aumentar os benefícios para pessoas fora do regime. Giambiagi e Além (2008) acrescentam que o INPS necessitava de recuperação financeira, devido à crise mundial dos anos 1970. Contudo, não houve comprometimento com o aumento das receitas para cobrir a ampliação dos benefícios.

Com o objetivo de aumentaras receitas, o governo adotou uma série de medidas. No dia 12 de abril de 1990, extinguiu o Ministério da Previdência Social e Assistência Social e reestabeleceu o Ministério do Trabalho e da Previdência Social. A parte da assistência social passou a ser responsabilidade do Ministério da Ação Social e a área

\footnotetext{
${ }^{10}$ Como é tradicional na história da Previdência Social, o regime demorou a ser implementado regularmente (Afonso, 2003).
} 
médica ficou a cargo do Ministério da Saúde, assim como o Instituto Nacional de Assistência Médica da Previdência Social (INAMPS). As modificações atingiram também o INPS e o IAPAS, que se juntaram e formaram o atual INSS por meio da lei n99.350 de 1990.

No ano seguinte foram estabelecidas a Lei $n^{\circ} 8.212$ da Seguridade Social e do Regime Geral da Previdência Social (RGPS), que instituiu seu novo Plano de custeio, e a Lei $\mathrm{n}^{\circ} 8.213$ do Plano de Benefícios da Previdência Social ${ }^{11}$ e foi criada a Contribuição para Financiamento da Seguridade Social (COFINS).

Os ajustes fiscais feitos no período 1989-1993 geraram uma redução no déficit de 6,4\% do PIB (GIAMBIATI; BARBOSA, 1995). Contudo, as políticas adotadas a fim de alavancar o sistema financeiro do sistema previdenciário não foram suficientes para equilibrar as despesas e as receitas.

Em 1995, o governo propôs várias medidas constitucionais com o intuito de alterar o quadro da previdência social brasileira e alterar os dispositivos que impediam uma reforma. Entretanto, apenas em 1998 foi erguido o acordo necessário para aprovação da Emenda Constitucional $n^{\circ} 20$ que permitiu a criação de leis com a finalidade de mudar os benefícios previdenciários, tanto para os trabalhadores do setor privado quanto para os servidores públicos.

As principais mudanças implementadas foram: mudança no critério para se aposentar, que antes era baseado nos anos de serviços e com a nova regra passou para anos de contribuição, tendo se estabelecido também um tempo mínimo de contribuição para obter o benefício; a exclusão da aposentadoria proporcional por tempo de serviço ${ }^{12}$; alteração nos cálculos do valor dos benefícios oriundos da introdução do fator previdenciário; término da aposentadoria especial dos professores universitários e aeronáuticos, entre outros; controle na concessão de isenção da contribuição patronal a empresas filantrópicas; a idade para aposentadoria dos servidores públicos por tempo de serviço passa a ter um limite mínimo (60 anos para homens e 55 para mulheres).

Segundo Najberg e Ikeda (1999), a emenda constitucional aprovada em 1998 foi um passo importantíssimo para o equilíbrio atuarial e financeiro da previdência, pois instituiu como principio básico o bom funcionamento das contas.

\footnotetext{
${ }^{11}$ As categorias de benefícios do plano são: aposentadoria por invalidez, idade, tempo de serviço e a aposentadoria especial; auxílio-doença; salário-maternidade; salário-família; pensão por morte; e auxilioreclusão. $\mathrm{O}$ valor mínimo dos benefícios era correspondente a um salário mínimo. O cálculo do saláriobenefício também foi modificado e passou a ser considerado como a média aritmética simples de todos os últimos 36 meses de salários de contribuição.

${ }^{12}$ É uma forma de se aposentar por ter completado 35 anos de contribuição.
} 
Segundo Afonso (2003), no Governo Fernando Henrique Cardoso (1995-1998) é notória a desarticulação entre o sucesso do Plano Real e a pouca eficiência nas tentativas de melhoramento no plano previdenciário. Um conjunto de fatores explica o que impedia a reforma previdenciária e os avanços na previdência social, tais como a ausência de clareza do governo em demonstrar um modelo previdenciário adequado, fragmentação política e as discussões prolongadas sobre as mudanças do INSS, RJU, seus privilégios e as diferenças em relação ao RGPS.

Em 1999 foi aprovada a lei $\mathrm{n}^{\circ} 9.876$ que alterou o calculo do benefício previdenciário. Até então era considerado a média dos 36 últimos salários de contribuição.Com a nova lei o valor do benefício passou a basear-se na media aritmética dos maiores salários de contribuição correspondentes a $80 \%$ de todo o período em que o segurado contribuiu para Previdência, corrigidos monetariamente. No mesmo ano, através do Decreto $\mathrm{n}^{\mathrm{o}} 3265$, foi criado o fator previdenciário com o objetivo de diminuir as aposentadorias precoces e aumentar a relação entre contribuição e benefícios. A fórmula do fator previdenciário $(f)$ é a seguinte:

$$
f=\frac{T_{C} \times a}{E_{S}} \times\left[1+\frac{I_{d}+T_{c} \times a}{100}\right]
$$

em que $T_{C}$ é o tempo de contribuição, $E_{S}$ é a expectativa de sobrevida no momento da aposentadoria, $I_{d}$ é a idade do trabalhador no momento da aposentadoria e $a$ é alíquota de contribuição do segurado.

Delgado e Cardoso(2000) relatam que o fator previdenciário foi consistente para minimizar os gastos da Previdência Social por meio do fluxo de concessão de Aposentadorias por Tempo de Contribuição (APCs). Segundo a avaliação sobre os dados, houve aumento na idade e contribuição e redução no valor dos benefícios dos que se aposentam por tempo de contribuição a partir da validade da lei.

Entretanto, a proposta do plano previdenciário no governo FHC, uma engenhosa maneira de vincular o valor do benefício à idade de aposentadoria, não causou grandes impactos no sistema previdenciário, principalmente no que se refere às aposentadorias do setor público, uma vez que a ideia generalizada de que os principais fatores do desequilíbrio ficaram intocados (NAKAHODO; SAVOIA, 2008).

Em 2003,o Ministério da Previdência e Assistência Social é transformado em Ministério da Previdência Social através da Lei ${ }^{\circ}$ 10683. Ainda nesse ano, acontece 
mais uma reforma previdenciária, mediante a emenda constitucional $n^{\circ} 41$, a qual modifica as regras de aposentadoria dos funcionários públicos e eleva o teto dos beneficiários do RGPS. Somente os trabalhadores que ingressaram na carreira pública após a data de aprovação da $\mathrm{EC} \mathrm{n}^{\circ} 41$ foram afetados.

De acordo com Silva (2004), o relatório final da comissão parlamentar decidiu os seguintes pontos:

- Aposentadoria integral, desde que cumpridos os requisitos de 10 anos na mesma profissão, 20 anos de serviço público, 35 e 30 anos de contribuição e 60 e 55 anos de idade para homens e mulheres, respectivamente;

- Beneficio calculado pela média das contribuições para os servidores que não cumprirem as exigências para a aposentadoria integral;

- Teto de salário e aposentadoria de $\mathrm{R} \$ 17.170,00$ para os funcionários públicos da União, Estados e municípios, subteto salarial igual ao salário do chefe de cada um dos três Poderes, e, para o Judiciário Estadual, teto de 75\% do salário do ministro do Supremo Tribunal Federal (STF);

- Teto de $\mathrm{R} \$ 2.400,00$ para ingressantes no serviço público e trabalhadores da iniciativa privada;

- Aposentadoria complementar por meio de fundo de pensão;

- Extinção da aposentadoria proporcional para servidores que ingressaram até 1998;

- Idade mínima de 55 anos para mulher e de 60 anos para o homem;

- Pensões integrais até o valor de $\mathrm{R} \$ 1.058,00$ e desconto mínimo de 30\% sobre a parcela excedente;

- Fim da paridade e correção dos benefícios pela inflação para servidores que não cumprirem requisitos para aposentadoria integral;

- Paridade parcial para aposentadorias integrais com correção restrita ao salário-base;

- Contribuição de $11 \%$ para inativos atuais e futuros sobre a parcela de benefícios superior a $\mathrm{R} \$ 1.058,00 ; \mathrm{e}$

- Alíquota mínima de contribuição de $11 \%$ para funcionários da União, Estados e municípios. 
Em 2005, a EC $n^{\circ} 41$ foi complementada pela $E C n^{\circ} 47$, que alterou algumas regras para aposentadoria dos funcionários públicos. Ela garante a paridade plena e possibilita a redução dos limites de idade para aposentadoria - 60 anos para homens e 55 para mulheres - se for excedido o tempo de contribuição exigido de 35 anos para homens e 30 para mulheres. Em relação ao RGPS, a EC n 47 aumentou a cobertura para os deficientes físicos, os trabalhadores de baixa renda e aos sem renda própria, tal como a dona de casa e os trabalhadores informais urbanos, assegurando o direito igual ao um salário mínimo de aposentadoria. Nesse grupo especial, as alíquotas eram menores em relação aos demais grupos do RGPS. Ainda em 2005, a Previdência Social começa a desenvolver o Censo Previdenciário com o intuito de atualizar os dados cadastrais de aposentados e pensionistas do INSS e aumentar a eficiência do sistema.

No ano seguinte, inicia-se a segunda etapa, que envolve14,7 milhões de aposentados e pensionistas. O anuário estatístico da Previdência Social mostra que houve um aumento no número de pessoas físicas contribuintes entre 2004 e 2006de 30,6 milhões para 33,3 milhões (um acréscimo de 8,9\%)(MPAS, 2014). Além disso, no ano de 2006 o RGPS necessitou de financiamento. Embora o número de contribuintes estivesse aumentando, a arrecadação liquida do RGPS foi calculada em R \$ 125,2 bilhões e as despesas com benefícios previdenciários em 167,9 bilhões.

O Quadro 1, elaborado por Reis (2012)resume os principais acontecimentos no desenvolvimento histórico da Previdência Social. Ao longo desses anos pouco se fala dos trabalhadores autônomos. Apenas no período 1930-1944 estes passam a ser cobertos pela previdência, porém não existiam políticas que direcionassem o trabalhador autônomo para a contribuição previdenciária. 


\begin{tabular}{|c|c|c|c|}
\hline Período & Característica & Evento & Cobertura \\
\hline Até 1930 & $\begin{array}{l}\text { Primeira } \\
\text { experiência e } \\
\text { inicio da } \\
\text { intervenção da } \\
\text { estatal } \\
\end{array}$ & Lei Eloy Chaves & $\begin{array}{l}\text { Pequeno número de } \\
\text { segurados, vinculação } \\
\text { por empresa }\end{array}$ \\
\hline 1930-1944 & $\begin{array}{l}\text { Consolidação da } \\
\text { interferência } \\
\text { governamental e } \\
\text { vinculação por } \\
\text { categorias } \\
\text { profissionais }\end{array}$ & $\begin{array}{l}\text { Inicio da fusão das CAPs } \\
\text { Criação das IAPs }\end{array}$ & $\begin{array}{c}\text { Expansão da cobertura } \\
\text { para trabalhadores } \\
\text { urbanos e boa parte dos } \\
\text { trabalhadores } \\
\text { autônomos, com } \\
\text { vinculação por } \\
\text { categoria profissional }\end{array}$ \\
\hline $1945-1965$ & $\begin{array}{l}\text { A caminho da } \\
\text { unificação } \\
\text { institucional }\end{array}$ & $\begin{array}{l}\text { Lei Orgânica da Previdência } \\
\text { Social (Lops) } \\
\begin{array}{l}\text { Estatuto do Trabalhador } \\
\text { Rural }\end{array}\end{array}$ & $\begin{array}{l}\text { Virtual totalidade dos } \\
\text { trabalhadores urbanos e } \\
\text { inserção dos } \\
\text { trabalhadores rurais }\end{array}$ \\
\hline $1966-1988$ & Expansão e Crise & $\begin{array}{l}\text { Criação do INPS } \\
\text { Criação do Pró-Rural } \\
\text { Criação do Ministério da } \\
\text { Previdência e Assistência } \\
\text { Social (MPAS) } \\
\text { Criação do Sistema Nacional } \\
\text { de Previdência e Assistência } \\
\text { Social (Sinpas) }\end{array}$ & $\begin{array}{c}\text { Totalidade das pessoas } \\
\text { que exercem atividade } \\
\text { remunerada (inclusive } \\
\text { trabalhadores rurais e } \\
\text { trabalhadores } \\
\text { domésticos) }\end{array}$ \\
\hline 1988-1997 & Seguridade Social & $\begin{array}{l}\text { Conceito integrado de } \\
\text { seguridade Social } \\
\text { Equiparação dos benefícios } \\
\text { urbanos e rurais } \\
\text { Diversificação da base de } \\
\text { financiamento } \\
\text { Piso unificado igual a um } \\
\text { salário mínimo para todos os } \\
\text { benefícios previdenciários e } \\
\text { assistenciais }\end{array}$ & $\begin{array}{c}\text { Universalização dos } \\
\text { direitos }\end{array}$ \\
\hline 1998-2002 & Reforma do RGPS & $\mathrm{EC} \mathrm{n}^{\circ} 20$ & Universal \\
\hline A partir de 2003 & $\begin{array}{l}\text { Reforma dos } \\
\text { RPPSs }\end{array}$ & $\begin{array}{l}E C n^{\circ} 41 \\
E C n^{\circ} 47\end{array}$ & Universal \\
\hline
\end{tabular}

Quadro 1: História da previdência social

Fonte: Reis (2012)

\subsection{O trabalhador autônomo e sua relação com a previdência social}

O trabalho autônomo engloba trabalhadores como vendedores ambulantes, camelôs, artesões, barbeiros, profissionais liberais (economistas, médicos, advogados etc.), entre outros. A primeira teoria sobre informalidade classificava o trabalho autônomo como uma ocupação informal. Para essa teoria, a informalidade envolvia 
atividades de baixa produtividade e rentabilidade e sem uma estrutura genuinamente empresarial. O trabalho autônomo era visto como uma alternativa ao desemprego, uma forma de manter os níveis básicos de subsistência para pessoas que foram excluídas do setor moderno e formal (HIRATA; MACHADO, 2007).

Nos dias atuais, nem todos os trabalhadores escolhem ser autônomos por falta de opção (por não conseguir um emprego assalariado). Em muitos casos, os trabalhadores optam por trabalhar por conta própria devido às suas características (habilidades e conhecimentos), pela liberdade de fazer outras coisas, devido ao histórico familiar na atividade, pela maior flexibilidade de trabalho, desejo de montar o próprio negócio, independência em relação a terceiros, ou pela possibilidade de auferir rendas maiores que no trabalho assalariado. Esse é o caso dos profissionais liberais, por exemplo (MACHADO; ANDRADE, 1994).

Sendo assim, os trabalhadores autônomos podem ser separados em dois grupos: os trabalhadores por conta própria; e os profissionais liberais ${ }^{13}$. O primeiro não exige formação técnica ou superior. É o caso de muitos pedreiros, encanadores, camelôs, etc. O segundo grupo exige conhecimento de alguma área em grau técnico ou universitário. Geralmente, médicos, economistas, advogados e administradores são profissionais liberais.

No Brasil, o crescimento do trabalho autônomo a partir do início da década de 1990 esteve bastante ligado à expansão da informalidade provocada pela política governamental de liberalização econômica, a qual afetou o mercado de trabalho e as relações socioeconômicas (GONÇALVES, 2011, AMADEO et al., 1994). A Erro! Fonte e referência não encontrada.evidencia a evolução do trabalhador autônomo brasileiro de 1940 a 2011.

\footnotetext{
${ }^{13}$ Classificação utilizada por Machado, Oliveira e Antigo (2008).
} 


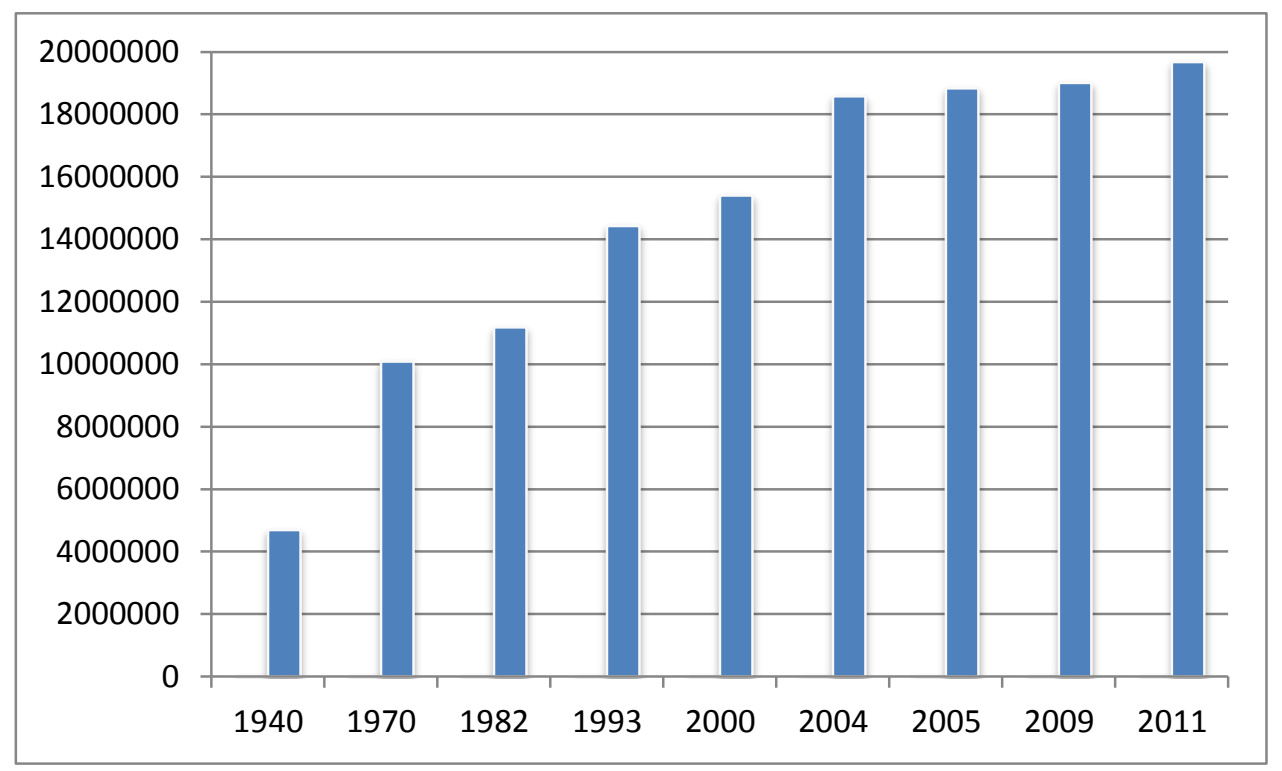

Figura 2- População de 10 anos e mais ocupada, total e trabalhadores por conta própria - Brasil - 1940/2011

Fonte: Elaborado pelo autor Holzman (2013) a partir dos dados do IBGE - Censo Demográfico (1940, 1970, 1982, 2000) - Anuário Estatístico do Brasil (1983), IBGE - PNAD (1993, 2004, 2005).

Um dos fatores que explicam o aumento da informalidade e do número de trabalhadores autônomos é a expansão no setor de serviços e retração na indústria de transformação (ULYSSEA, 2005).

A relação do trabalhador autônomo com a previdência social é peculiar. Diferentemente do que acontece com outros trabalhadores como assalariados com carteira de trabalho assinada e funcionários públicos, a cobertura previdenciária do trabalhador autônomo depende do seu desejo de ser ou não um contribuinte da previdência. Essa decisão está relacionada a fatores como compreensão dos benefícios, suficiência de renda e aversão ao risco associado à perda da capacidade laboral por doença, velhice etc. (GALEAZZI, 1994).

No Brasil, grande parte dos trabalhadores autônomos não teria acesso a aposentadoria caso não contribuíssem para a previdência social. Muitos preferem ficar excluídos do sistema, seja pela falta de informação, pela alta mobilidade, por subestimar as possíveis privações futuras, por acreditar que não precisarão dos benefícios da previdência ou pelo peso da contribuição no orçamento (CORSEUIL; REIS, 2011).

Além disso, pela forma como evoluiu a previdência social brasileira, é notável que não houve discernimento entre os trabalhadores assalariados e os trabalhadores autônomos, pois não houve políticas especificas para última ocupação. 
Somente em 2006, com o Estatuto Nacional da Microempresa e da Empresa de Pequeno Porte, criou-se incentivos para micro e pequenos empresários. Entretanto, na medida em que a política estava sendo implementada, observou-se que não estava atingindo muitos dos trabalhadores autônomos.

Em 2008, a Lei complementar 128 estabeleceu como pessoa jurídica a figura do Microempreendedor Individual (MEI) para incentivar a contribuição previdenciária e legalizar os pequenos negócios. Até junho de 2014, mais de quatro milhões de microempreendedores registram-se em todo o país. Para obter o registro e enquadrar-se como MEI é necessário desempenhar algumas dessas atividades: artesão, pedreiro, açougueiro, cabeleireiro, mecânico, eletricista, fotógrafo, entre outros. É considerado empresário individual aquele que trabalha de forma independente e que se legaliza como pequeno empresário (PORTAL DO EMPREENDEDOR, 2015). Os principais direitos que se destacam nesse novo cenário são:

- Acesso à previdência social - o trabalhador contribui com uma taxa mensal diferenciada de 5\%sobre o salário mínimo, passando a ter direito, juntamente com sua família, a auxílio-doença, aposentadoria por idade, aposentadoria por invalidez, pensão por morte, auxilio-reclusão e salário maternidade;

- Direito de contratar um empregado pagando menores encargos trabalhistas $-3 \%$ sobre o salário mínimo para a previdência e $8 \%$ para o FGTS;

- Menos impostos - valor fixado em $\mathrm{R}$ 5,00 para atividades de prestação de serviços (ISS) e R \$ 1,00 para atividades relacionadas ao comércio e indústria (ICMS).Esse valor é único, independentemente do volume produzido;

- Registro da empresa - todo o processo de formalização é gratuito. O único gasto é a contribuição para a previdência social e o pagamento de impostos mensalmente; e

- Consultoria do SEBRAE - diante da necessidade de qualquer orientação ou assessoria, o SEBRAE oferece cursos e planejamentos de negócios para melhor gerir a empresa. 
Tais benefícios incentivam o trabalhador autônomo à formalização empresarial e previdenciária. No entanto, é necessário ressaltar que nem todo trabalhador autônomo pode ser considerado um Microempreendedor Individual (MEI), pois depende da atividade desempenhada e a receita anual não pode ultrapassar de $\mathrm{R} \$ \mathbf{6 0 . 0 0 0 , 0 0}$ (PORTAL DO EMPREENDEDOR, 2015).

Além dessa nova possibilidade de formalização, o trabalhador autônomo também pode contribuir para a previdência social através do Plano Simplificado de Previdência Social (PSPS). Esse plano permite a formalização previdenciária com uma contribuição de $11 \%$ sobre o valor do salário mínimo. Os trabalhadores que têm direito a esse programa são os que não têm vínculo de trabalho com empresas ou equiparada, isto é, não possuem uma empresa registrada. Os benefícios são os mesmos do MEI: aposentadoria por idade, auxílio-doença, salário- maternidade, pensão por morte, auxílio-reclusão e aposentadoria por invalidez.

Outra forma de o trabalhador autônomo contribuir para previdência social é por meio da alíquota de $20 \%$ sobre o rendimento. Nesse caso, além de se beneficiar dos direitos dos outros programas, é acrescido o direito de aposentadoria por tempo de contribuição (30 anos para mulheres e 35 anos para homens).

Diante dessas questões, o presente trabalho pretende analisar mais afundo a relação entre o trabalhador autônomo e a previdência social, focando no papel exercido pelas características socioeconômicas e demográficas desse trabalhador sobre sua decisão de contribuir ou não para a previdência.

De acordo com Santiago (2014), uma análise detalhada sobre a relação do trabalhador autônomo com a previdência social faz-se necessária por causa de dois motivos: 1) esse profissional responde por 41,6\% do emprego informal em um grupo de treze países na América Latina ${ }^{14}$; e 2) preocupação com uma política específica e diferenciada para essa categoria no governo brasileiro.

\footnotetext{
${ }^{14}$ Os países mencionados são Argentina, Brasil, Colômbia, Costa Rica, Equador, El Salvador, Honduras, México, Panamá, Paraguai, Peru, República Dominicana e Uruguai.
} 


\section{REFERENCIAL TEÓRICO}

\subsection{Demanda por seguros}

A tomada de decisão de contribuir ou não com a previdência social do trabalhador autônomo pode ser compreendida como um processo de escolha complexo, uma vez que é difícil sacrificar o consumo de hoje para o consumo de amanhã. Se os autônomos fossem capazes de calcular o quanto precisariam futuramente, estariam preparados para situações de perda laboral(CORSINI; PACINI; SPATARO, 2012).

Nesse sentido, Melguizo, Bosch e Pagés (2013) afirmam que um dos elementos que impedem os indivíduos de poupar para o longo prazo é a incerteza, que envolve uma série de dúvidas por causa da pouca ou nenhuma informação sobre as variáveis principais que determinam a poupança de longo prazo.

Barr e Diamond (2006) completam que a incerteza presente no financiamento de aposentadoria e pensões é um problema de falta de informação. Segundo os autores, na microeconomia tradicional os consumidores apresentam informação completa, mas esta hipótese é muito forte para estudar as decisões de poupança para o longo prazo.

Baseado em Mas-Colell, Whinston e Green (1995) e Varian (1992), a informação incompleta implica que os trabalhadores autônomos não conheçam seus riscos de perdas e ganhos no momento da decisão de contribuir ou não para previdência social. Sua escolha torna-se dependente das probabilidades de perdas e ganhos. Deste modo, faz-se necessário entender a contribuição arbitrária como demanda de seguros para compreender a escolha dos autônomos.

São vários os fatores que podem influenciar a demanda por seguro. Por exemplo, urbanização, renda e suas distribuições, população e o nível da educação são fatores relevantes para o desenvolvimento do setor de seguros. Dragos (2014), utilizando dados em painel em 17 países emergentes da Ásia e Europa, identificou que os fatores mencionados tem diferentes efeitos para o seguro.

Truett e Truett (1990) buscam examinar os determinantes da demanda por seguro de vida nos Estados Unidos e no México. Os autores apontam que idade, educação e nível de renda são fatores que afetam a demanda por seguros de vida. Um dos achados mais interessantes foi o fato de a elasticidade-renda da demanda por seguros de vida ser mais elevada no México do que nos Estados Unidos e a elasticidade- 
renda da demanda para seguros de vida ser mais elevada para valores mais baixos de renda.

Showers e Shotick (1994), através de um modelo Tobit, analisam o impacto de fatores econômicos e sociais na aquisição de seguros pelas famílias utilizando dados de uma pesquisa nacional dos gastos do consumo nos Estados Unidos realizada no ano de 1987. Constataram que a probabilidade de uma família adquirir um seguro é de $90 \%$, que a elasticidade-renda da demanda é baixa, que famílias com apenas uma pessoa gerando renda sentem-se mais inseguras do que uma família com dois ou mais pessoas gerando renda, que um aumento na idade do chefe da família aumenta o desejo das famílias de reduzir risco, que cerca de $73 \%$ das famílias mais novas possuem algum seguro enquanto que apenas $58 \%$ das mais velhas o fazem, e que a relação entre tamanho da família e gastos com seguro é positiva.

Em pesquisa abordando as empresas de seguro da Malásia, Loke e Goh (2012) identificaram os fatores que conduzem as pessoas a procurar o seguro de vida, utilizando uma regressão logística em uma amostra de 500 entrevistados. Eles encontraram que várias características socioeconômicas explicam a demanda por seguro de vida, tais como idade, renda, ocupação, aversão ao risco etc.

Beck e Webb (2002) procuram os fatores que levam a grande variação na demanda por seguro entre países, utilizando um painel com dados agregados em diferentes frequências para 68 países durante o período de 1961-2000. Esse estudo constatou que as variáveis econômicas, tais como a inflação, renda per capita, bem como indicadores religiosos e institucionais são preditores mais fortes para uso de um seguro de vida.

Ainda em âmbito internacional, Zietz (2003) faz uma revisão de literatura relacionada aos fatores econômicos e demográficos que podem ser determinantes como características para demanda de seguro de vida. Três fatores são fundamentais: inflação, as leis e a riqueza.

No Brasil, Andrade e Maia (2007) verificaram os determinantes da demanda e da escolha do grau de cobertura por planos de saúde privado utilizando como banco de dados a Pesquisa Nacional por Amostra Domiciliar (PNAD) de 1998 e 2003. Para a análise da demanda por plano de saúde foi usada a regressão logística e para a escolha de cobertura do plano utilizou-se o modelo logit multinomial. Os resultados mostraram que a renda é a principal variável explicativa e que ela ganha relevância quando se analisa a demanda por plano individual. Na escolha de cobertura do plano de saúde, o 
plano ambulatorial tem mais chances de ser escolhido em relação à cobertura completa, quanto mais jovem for o indivíduo, quanto menor for seu poder de compra e quanto menor for sua a escolaridade.

Bahia et al. (2002) investigaram a presença de risco moral e seleção adversa na demanda por planos de saúde utilizando-se dos dados da PNAD de 1998. Compararam as pessoas que possuem plano de saúde por causa do vinculo do trabalho com aqueles que procuram individualmente e os que os demandam o serviço do Sistema Único de Saúde (SUS). Utilizando a regressão logística com múltiplos controles, em que a variável de desfecho é indicadora de seleção adversa ou risco moral. Os resultados não deixam claro o problema de informação assimétrica, no entanto, mostram que é preciso estudar mais as relações entre a morbidade, utilização de serviços de saúde e gastos com saúde e tipo de cobertura.

De maneira similar, Maia et al. (2004) detectam a presença de risco moral no sistema de saúde brasileiro a partir de uma análise contra-factual. Foram escolhidas duas variáveis de utilização do cuidado médico: consultas médicas e dias de internação. Para as consultas médicas, o valor estimado foi de 1,05 consultas per capita por anos e dias de internação 0,42 dias per capita, na última internação dos últimos doze meses. Esses resultados indicam risco moral porque os preços praticados estão acima do nível ótimo, gerando perdas de bem-estar.

\subsection{Modelo Teórico}

Diversos motivos dificultam ao trabalhador autônomo poupar durante muitos anos para financiar seu consumo futuro: insuficiência de renda, fatores que alteram o comportamento, incerteza e a falta de informação. Nesse sentido, para estudar a escolha do autônomo em relação à contribuição previdenciária (uma espécie de seguro) é necessário especificar a utilidade do indivíduo diante de incertezas.

Antes de falar propriamente da escolha dos agentes sob incerteza é importante saber que risco e incerteza são conceitos distintos. O primeiro diz respeito a situações em que embora não se saiba ao certo qual evento acontecerá, os eventos vêm associados a probabilidades de ocorrência. Por outro lado, incerteza refere-se a eventos em que os agentes econômicos não conseguem associar, de forma objetiva, valores de probabilidade (LAZZAROTTO; COSTA; SANTOS, 2009). 
Na teoria econômica, é possível utilizar a teoria da utilidade para analisar a escolha dos consumidores mesmo em situações de incerteza. Contudo, existem diferenças entre as funções de utilidades em ambientes de certeza e incerteza. A escolha sob incerteza influencia com o comportamento dos agentes econômicos, que podem ser mais ou menos propensos a aceitar certas probabilidades de ganhos ou perda.

A Tabela 1 sintetiza as possibilidades de obtenção de renda pelos trabalhadores autônomos ao longo da vida, em cada estado da natureza, contribuindo ou não para previdência social.

Tabela 1 - Possibilidades de renda dos trabalhadores autônomos ao longo da vida segundo o estado de contribuição e o estado da natureza

$\begin{array}{lll}\text { Estado de contribuição } & \text { Estado da natureza } & \text { Renda obtida }\end{array}$

\begin{tabular}{llc}
\hline Não-contribuinte & Sem injúrias & $x_{2}$ \\
& Com injúrias & $x_{1}$ \\
\hline Contribuinte & Sem injúrias & $E(x)-\pi_{i}$ \\
& Com injúrias & $E(x)-\pi_{i}$ \\
\hline
\end{tabular}

Fonte: Elaborado pelo autor.

Os autônomos procuram maximizar a utilidade esperada. A utilidade esperada do autônomo que não contribui para a previdência social é:

$$
U E_{N C}=p_{i} U\left(x_{1}\right)+\left(1-p_{i}\right) U\left(x_{2}\right)
$$

Caso o autônomo contribua para previdência social, sua utilidade esperada é constante entre os dois estados da natureza e dada por:

$$
U E_{c}=U E\left(E(x)-\pi_{i}\right)
$$

Considerando-se que o seguro previdenciário seja atuarialmente justo (a previdência opera com lucro zero), o trabalhador autônomo só contribui para previdência social quando a utilidade esperada de contribuir for maior que a de não contribuir: 


$$
\begin{gathered}
U E_{c}>U E_{N C} \\
U E\left(E(x)-\pi_{i}\right)>p_{i} U\left(x_{1}\right)+\left(1-p_{i}\right) U\left(x_{2}\right)
\end{gathered}
$$

A desigualdade da equação acima aponta que quanto menor a probabilidade de o autônomo sofrer uma injúria que comprometa sua capacidade laboral (quanto mais próximo de zero $\operatorname{estiver}_{i}$ ), menor será a possibilidade de ele contribuir para a previdência social, pois nesse caso a utilidade esperada de não contribuir será maior que a de contribuir. Além disso, quanto mais côncava a função de utilidade do trabalhador (quanto mais avesso ao risco), maior será a chance de ele contribuir para a previdência social.

\section{METODOLOGIA}

\subsection{Modelo econométrico}

O trabalhador autônomo deve decidir se contribui ou não para a previdência social. Ao modelar essa situação, a variável de resposta pode assumir dois valores, isto é, a contribuição previdenciária é uma variável binária. Para atender tal problema, utilizam-se modelos de escolha qualitativa. Neste trabalho, optou-se por utilizar o modelo Logit, embora o modelo Probit atenda também a este critério (GREENE, 2008) $)^{15}$. Para estimar a probabilidade de o autônomo i contribuir para a previdência é necessário, inicialmente, linearizar a função de distribuição acumulada logística

$$
P_{i}=P\left(Y_{i}=1\right)=F\left(X_{i} \beta\right)=\frac{1}{1+e^{-\left(X^{\prime} \beta\right)}}
$$

Assim, a equação a ser estimada é

$$
L_{i}=X^{\prime} \beta+\varepsilon_{i}
$$

\footnotetext{
${ }^{15}$ Para maiores detalhes, consultar Greene (2008).
} 
em que:

$L_{i}=\ln \left(\frac{P_{i}}{1-P_{i}}\right)$ é uma variável binária igual a 1 se o autônomo i contribui para previdência e 0 se ele não contribui;

$\beta$ é um vetor de parâmetros a serem estimados;

$X^{\prime}$ é a matriz dos regressores; e

$\varepsilon_{i}$ é a perturbação aleatória.

Serão estimados dois modelos: um modelo para o profissional liberal e outro para outros autônomos. As variáveis explicativas consideradas nos modelos são ${ }^{16}$ :

i. Sexo: é variável dummy que assume valor 1 se o indivíduo é homem e 0 , caso contrário;

ii. Idade: idade do indivíduo, em anos;

iii. Idade ao quadrado: idade do indivíduo elevada ao quadrado;

iv. Escolaridade: anos de estudo do indivíduo;

v. Renda: renda mensal do trabalhador autônomo, de todas as fontes, em reais;

vi. Renda ao quadrado: renda mensal elevada ao quadrado;

vii. Grupo de atividade econômica: oito variáveis dummies para os grupos de atividades econômicas exercidas pelos autônomos (outras atividades industriais; construçãocivil; comércio e reparação; alojamentos e alimentação; transporte, armazenagem e comunicação; educação, saúde e serviços sociais; outros serviços; e outras atividades). A categoria-base é indústria e transformação;

viii. Região: variáveis dummies para a região de residência dos indivíduos (Norte, Sul, Centro-Oeste e Nordeste). A categoria-base é sudeste;

ix. Componentes no domicílio: número de indivíduos residentes no domicílio em que o trabalhador autônomo vive.

Como existe possibilidade de relação linear entre algumas variáveis (escolaridade, renda e idade), é necessário fazer o teste de correlação, pois o problema de colinearidade alta dificulta a estimação dos parâmetros com maior precisão, ou seja, os coeficientes da regressão terão erros-padrão altos. Esse teste - coeficiente de correlação de Pearson - possibilita medir a colinearidade das variáveis, que pode assumir valores entre -1 e 1 . Quando o valor é igual a 1 , diz-se que há colinearidade

\footnotetext{
${ }^{16}$ A escolha das variáveis explicativas baseou-se em estudos sobre demanda de seguro como os de Truett e Truett (1990), Showers e Shotick (1994), Loke e Goh (2012) e Outreville (2013).
} 
perfeita positiva entre as duas variáveis. Se o valor for -1 , interpreta-se como colinearidade perfeita negativa. Caso o valor seja 0 , significa que não existe colinearidade. Pesquisadores consideram valores acima de 0,7 como valores altos de correlação, entre 0,3 a 0,7 como valores moderados e valores abaixo de 0,3 significa fraca correlação entre as duas variáveis (GREENE, 2008).

O método utilizado para estimar o modelo Logit é a Máxima Verossimilhança (MV). Como o presente trabalho utiliza o banco de dados da PNAD que incorpora todas as características de um plano amostral complexo, não é possível utilizar MV. Desse modo, o modelo utilizado é Máxima Pseudo-Verossimilhança (MPV).

De acordo com Silva, Pessoa e Lila (2002), os aspectos que descrevem o plano amostral complexo são: estratificação, conglomeração, probabilidades distintas em relação em um ou mais estágios e ajustes dos pesos amostrais com totais populacionais conhecidos. Assim sendo, os dados retirados da PNAD não podem ser tratados como se fossem sido geradas de amostras aleatória simples, tal qual são observações independentes e identicamente distribuídas na qual exibem probabilidade de seleção igual.

Os pesquisadores utilizam os dados da PNAD para análises descritivas, medidas de dispersão e para a construção e ajuste de modelos em análises secundárias, como por exemplo, modelos de regressão, modelos de regressão logística, modelos de regressão multinominal logística, e outros. Vale lembrar que é necessário incorporar os pesos, pois quando são considerados nos cálculos - os pesos das unidades amostrais disponíveis nos arquivos de microdados- asseguram que as estimativas obtidas para os parâmetros populacionais sejam não-viesadas e consistentes.

Os parâmetros estimados da equação (6) não informam diretamente os efeitos marginais das variáveis explicativas sobre a probabilidade de o autônomo contribuir para a previdência. No caso de variáveis explicativas contínuas, o efeito marginal pode ser calculado por

$$
\frac{\partial P_{i}}{\partial X_{i j}}=P_{i}\left(1-P_{i}\right) \beta_{i}
$$

O efeito marginal representa o impacto de uma variação em uma unidade na variável explicativa sobre a probabilidade (em pontos percentuais) de i-ésimo individuo contribuir para a previdência, ceteris paribus. Em relação às variáveis explicativas 
discretas (dummies), o efeito marginal indica qual a variação na probabilidade de o individuo i contribuir se a variável passa do valor zero para o valor um.

\subsection{Fonte de dados}

Os pesquisadores dos problemas socioeconômicos têm como suporte várias fontes de levantamentos de dados, de modo que investigam várias características dos indivíduos, como aquelas relacionadas à habitação, rendimento, trabalho, educação, entre outros. Uma das mais importantes fontes no Brasil é o Instituto Brasileiro de Geografia e Estatística (IBGE), responsável pela realização dos censos demográficos, da Pesquisa Mensal de Emprego(PME), da Pesquisa de Orçamento Familiar(POF) e da Pesquisa Nacional por Amostras de Domicílios(PNAD). Esta última baseia-se em uma amostra complexa de domicílios, executada em todo o Brasil, sendo sua população-alvo os domicílios e as pessoas residentes.

Para a realização do presente trabalho, foram utilizados os dados da PNAD de 2013, publicado em 2014 pelo Instituto Brasileiro de Geografia e Estatística(IBGE). A importância da utilização da PNAD está relacionada ao significativo número de informações individuais contidas na pesquisa, chamados de microdados. A consistência destas informações está na possibilidade de desagregação dos dados da pesquisa em seu menor grau possível, isto é, os microdados permitem o acesso minucioso das informações de milhares de pessoas e maior precisão nos resultados estimados, por meio de informações socioeconômicas de cada indivíduo.

O corte da amostra é composto por 30.788 trabalhadores autônomos urbanos maiores de 16 anos que estão ativos na ocupação (essa amostra representa uma população de 14.626.461 autônomos no Brasil). Os trabalhadores rurais autônomos foram excluídos da amostra, pois eles se enquadram na categoria de segurados especiais da Previdência Social. Os indivíduos aposentados também foram retirados da amostra, uma vez que eles não têm os mesmos incentivos para contribuir para a previdência. Além disso, essas restrições permitem reduzir as chances de viés de seleção.

\section{RESULTADOS E DISCUSSÃO}

\subsection{O trabalhador autônomo e sua relação com a previdência social}


De acordo com a Tabela 2, a maior parte dos trabalhadores brasileiros se enquadra na categoria empregados com carteira assinada. A Figura 3 mostra que, em média, 30\% dos trabalhadores brasileiros não contribuem com a previdência social. Entre os trabalhadores autônomos, $71 \%$ não contribuem. O mesmo acontece com $99 \%$ dos militares, $78 \%$ dos trabalhadores sem carteira assinada e 94\% trabalhadores na construção para o próprio uso ${ }^{17}$.

Tabela 2 - Número de trabalhadores, segundo a posição na ocupação no trabalho principal e contribuição para a previdência social, Brasil, 2013

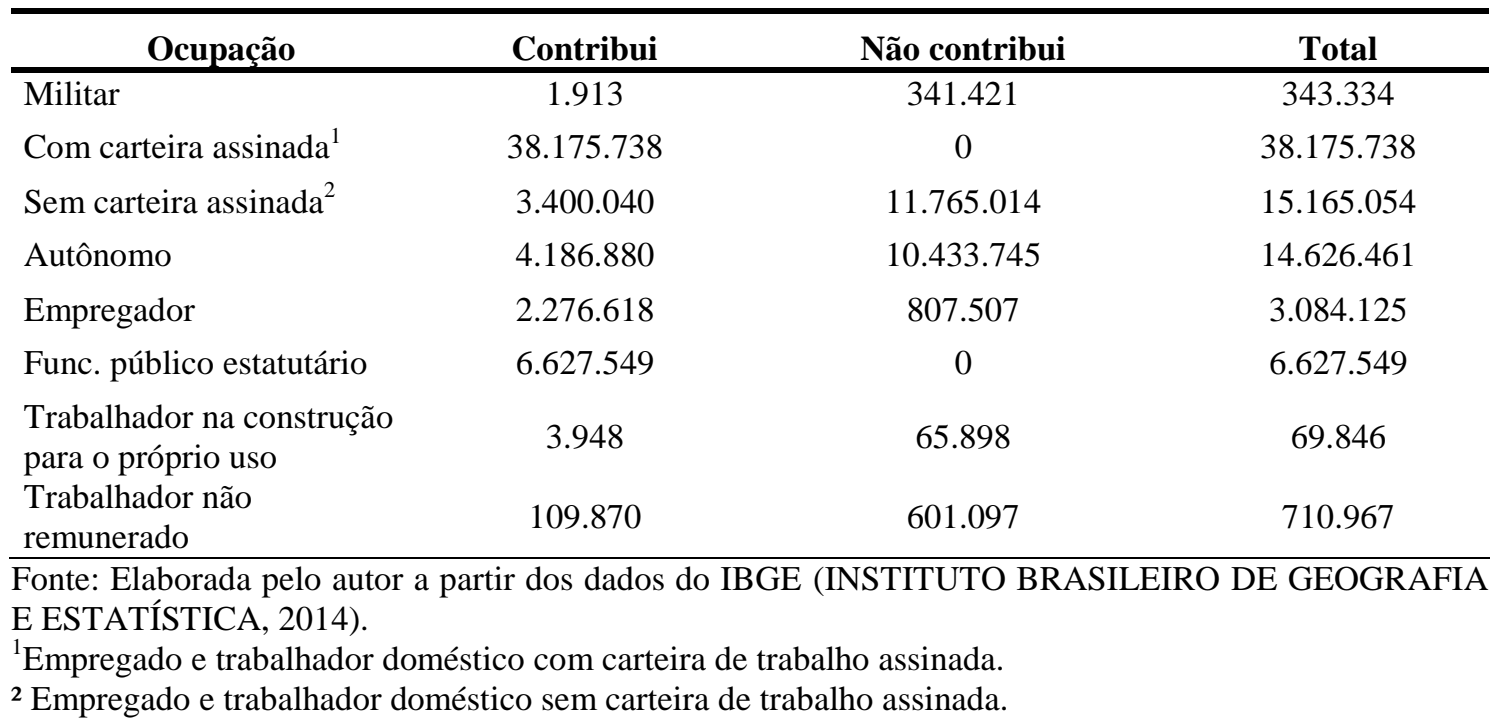

\footnotetext{
${ }^{17}$ Os servidores civis e militares da União, dos Estados, dos Municípios, dos Territórios e do Distrito Federal possuem um regime próprio de previdência.
} 


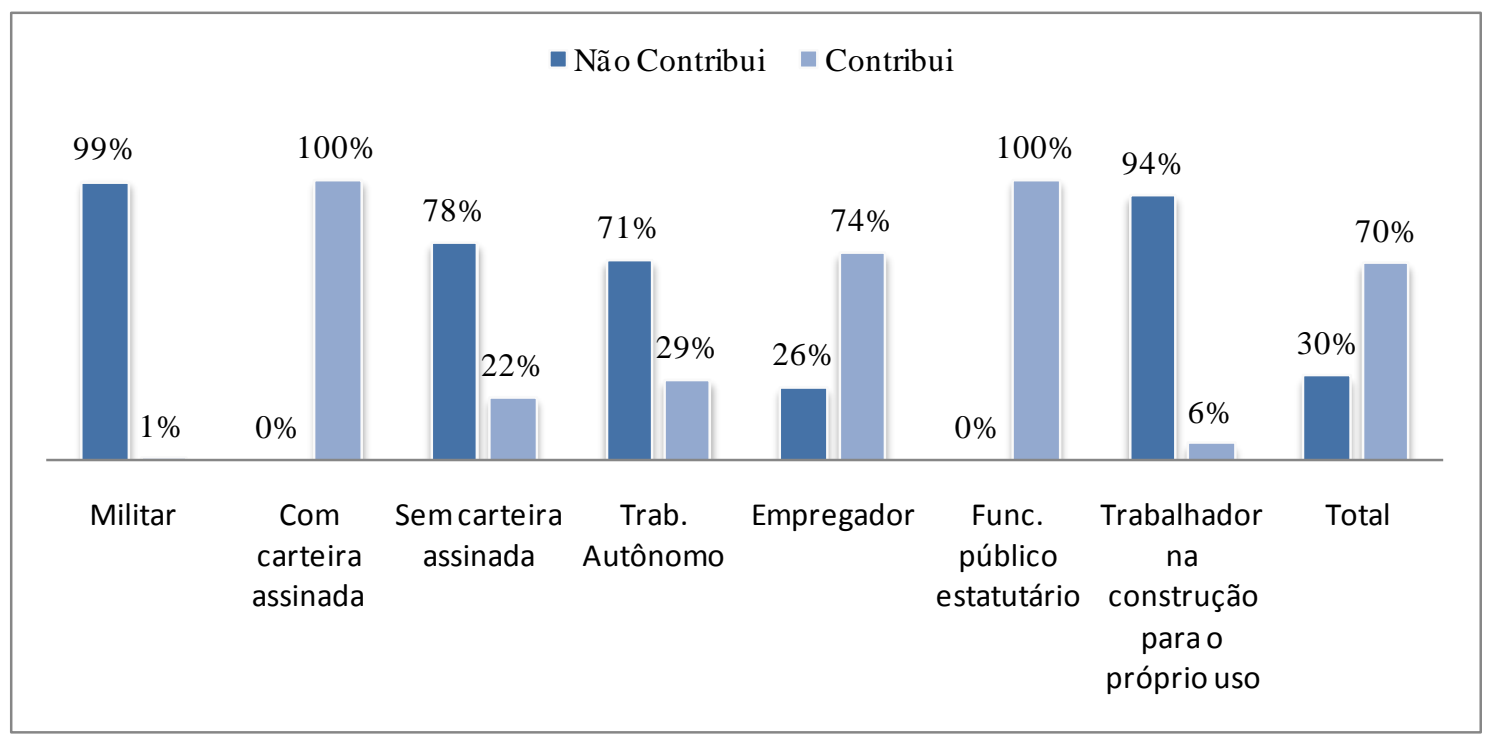

Figura 3 - Percentual de trabalhadores contribuintes para a previdência social, segundo a posição na ocupação no trabalho principal, Brasil, 2013

Fonte: Elaborada pelo autor a partir dos dados do IBGE (INSTITUTO BRASILEIRO DE GEOGRAFIA E ESTATÍSTICA, 2014).

Os trabalhadores autônomos podem ser divididos em dois grupos: os profissionais liberais e os demais trabalhadores por conta própria. O primeiro grupo exige conhecimento de alguma área em grau técnico ou universitário. Geralmente, médicos, economistas, advogados e administradores são profissionais liberais. O segundo grupo não exige formação técnica ou superior. É o caso de muitos pedreiros, encanadores, camelôs etc. De acordo com a Tabela 3, a maior parcela dos trabalhadores autônomos não são profissionais liberais (93,5\%). Contudo, o percentual de profissionais liberais que contribui para a previdência é maior que o dos demais autônomos (59\% dos profissionais liberais, contra $27 \%$ dos demais trabalhadores por contra própria, conforme mostra a Figura 4).

Tabela 3 - Número de trabalhadores autônomos urbanos, segundo a contribuição para a previdência social, por categoria de trabalhador autônomo, Brasil, 2013

\begin{tabular}{lccc}
\hline \multicolumn{1}{c}{ Trab. Autônomo } & Contribui & Não contribui & Total \\
\hline Profissional liberal & 557.560 & 394.740 & 952.300 \\
Outros autônomos & 3.629 .320 & 10.039 .005 & 13.668 .325 \\
Total & 4.186 .880 & 10.433 .745 & 14.620 .625
\end{tabular}

Fonte: Elaborada pelo autor a partir dos dados do IBGE (INSTITUTO BRASILEIRO DE GEOGRAFIA E ESTATÍSTICA, 2014).

Como visto, o percentual de trabalhadores autônomos protegidos pela previdência social é menor que a metade da média brasileira. Além disso, dos que não 
contribuem para previdência social, aproximadamente 95\% também não possuem previdência privada.

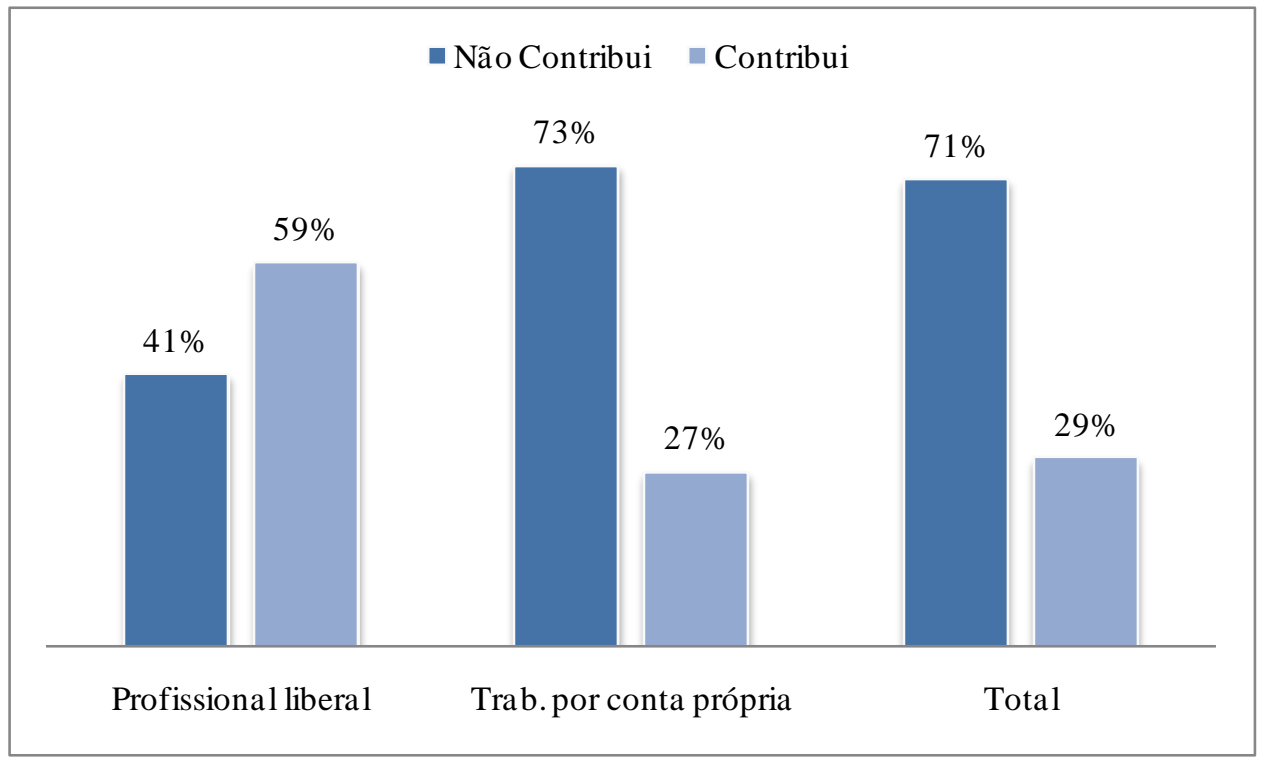

Figura 4 - Percentual de trabalhadores autônomos urbanos contribuintes para a previdência social, por tipo de trabalhador autônomo, Brasil, 2013

Fonte: Elaborada pelo autor a partir dos dados do IBGE (INSTITUTO BRASILEIRO DE GEOGRAFIA E ESTATÍSTICA, 2014).

De acordo com a Tabela 4, o número de trabalhadores autônomos do sexo masculino é quase o dobro do número de trabalhadores do sexo feminino. O percentual de contribuintes entre as mulheres (27\%) é um pouco menor que o verificado entre os homens (30\%), como mostra a Figura 5.

Tabela 4 - Número de trabalhadores autônomos urbanos, segundo a contribuição para a previdência social, por gênero, Brasil, 2013

\begin{tabular}{lccc}
\hline \multicolumn{1}{c}{ Sexo } & Contribui & Não Contribui & Total \\
\hline Feminino & 1.426 .745 & 3.152 .400 & 5.279 .145 \\
Masculino & 2.761 .491 & 6.585 .825 & 9.347 .316 \\
\hline Total & 4.188 .236 & 10.438 .225 & 14.626 .461 \\
\hline
\end{tabular}

Fonte: Elaborada pelo autor a partir dos dados do IBGE (INSTITUTO BRASILEIRO DE GEOGRAFIA E ESTATÍSTICA, 2014). 


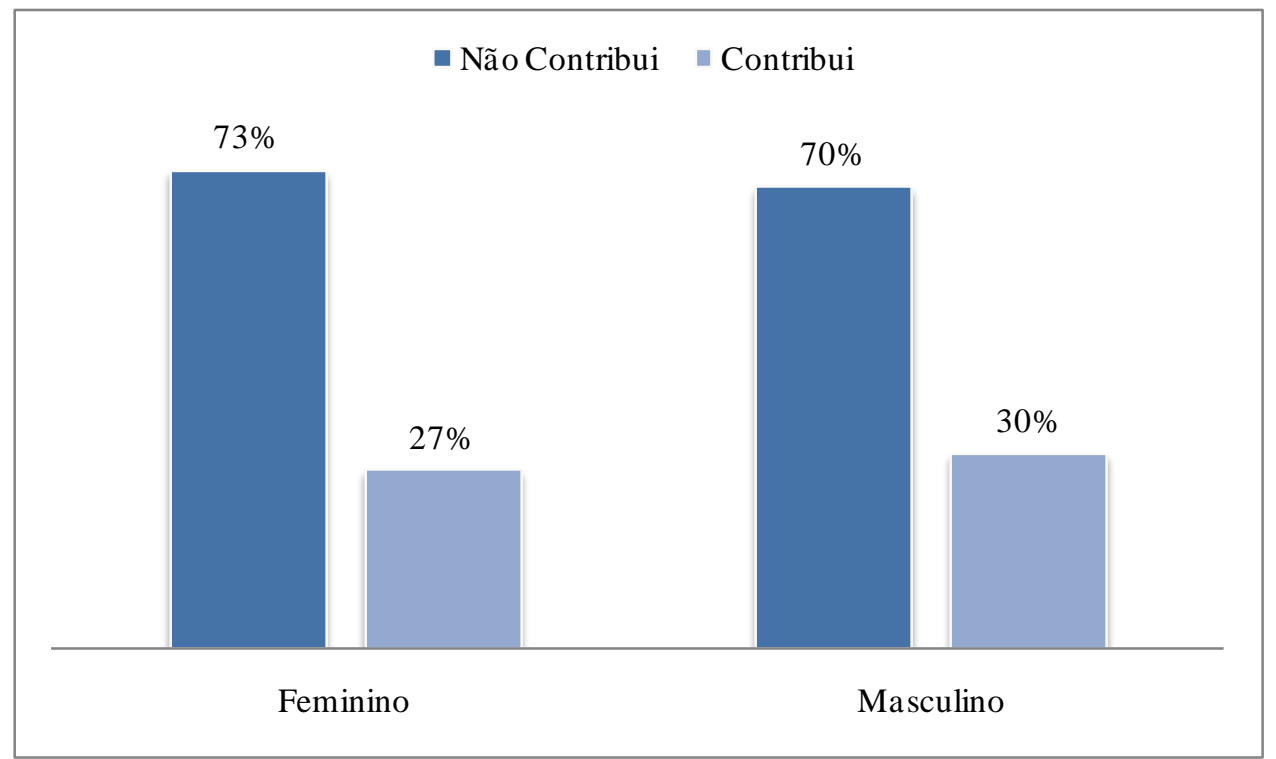

Figura 5 - Percentual de trabalhadores autônomos urbanos contribuintes para a previdência social, por gênero, Brasil, 2013

Fonte: Elaborada pelo autor a partir dos dados do IBGE (INSTITUTO BRASILEIRO DE GEOGRAFIA E ESTATÍSTICA, 2014).

A Tabela 5 mostra que há uma maior concentração de trabalhadores autônomos na faixa etária 40 a 49 anos (4.085.043 trabalhadores) no Brasil. De acordo com aFigura 6, o percentual de autônomos que contribui com a previdência social tende a crescer com a idade até certo ponto e depois decresce.

Tabela 5 - Número de trabalhadores autônomos urbanos, segundo a contribuição para a previdência social, por grupos de idade, Brasil, 2013

\begin{tabular}{lccc}
\hline \multicolumn{1}{c}{ Idade } & Contribui & Não contribui & Total \\
\hline 16 a 19 anos & 18.466 & 311.255 & 329.721 \\
20 a 29 anos & 416.598 & 1.788 .049 & 2.204 .647 \\
30 a 39 anos & 1.059 .917 & 2.828 .446 & 3.888 .363 \\
40 a 49 anos & 1.290 .935 & 2.794 .108 & 4.085 .043 \\
50 a 59 anos & 1.089 .836 & 2.010 .347 & 3.100 .183 \\
60 anos ou mais & 312.484 & 706.020 & 1.018 .504 \\
\hline
\end{tabular}

Fonte: Elaborada pelo autor a partir dos dados do IBGE (INSTITUTO BRASILEIRO DE GEOGRAFIA E ESTATÍSTICA, 2014). 


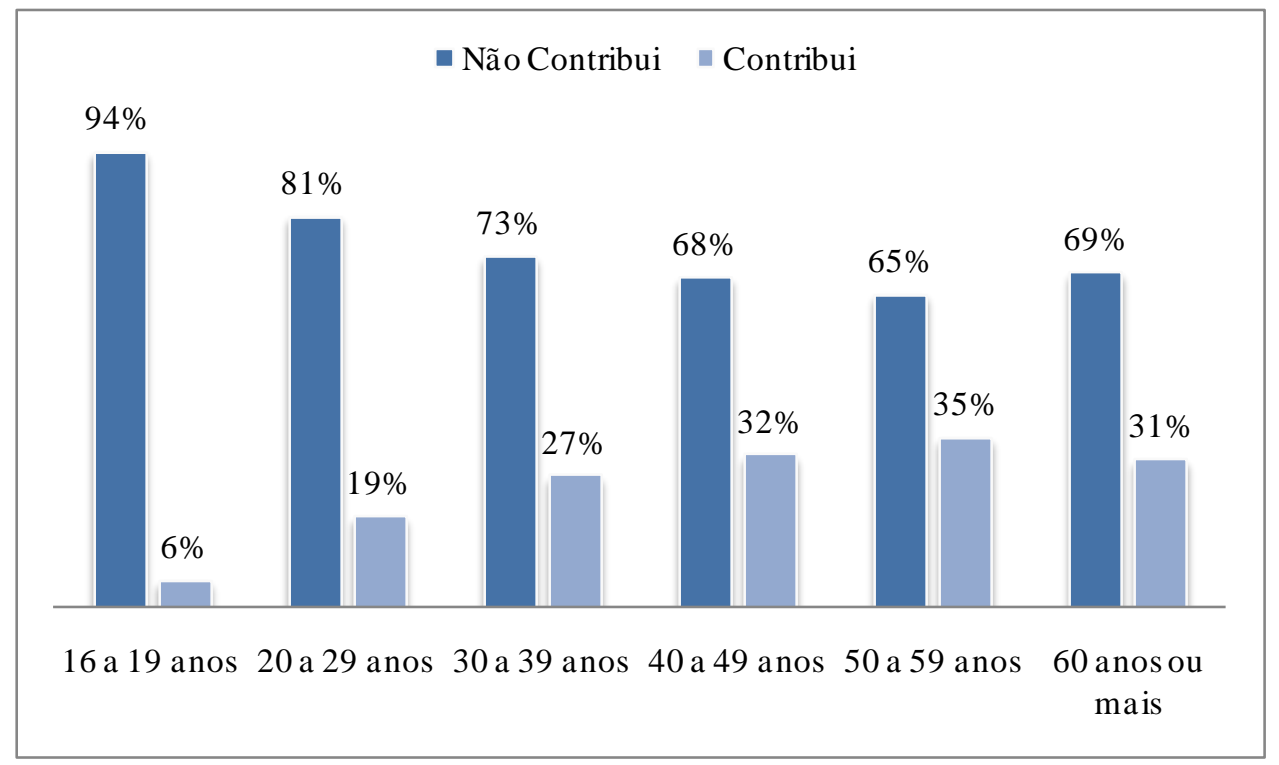

Figura 6 - Percentual de trabalhadores autônomos urbanos contribuintes para a previdência social, por grupos de idade, Brasil, 2013

Fonte: Elaborada pelo autor a partir dos dados do IBGE (INSTITUTO BRASILEIRO DE GEOGRAFIA E ESTATÍSTICA, 2014).

De acordo com a Tabela 6, há uma maior concentração de autônomos com 12 a 15 anos de estudo. Além disso, a contribuição previdenciária tem uma relação direta com a escolaridade, conforme se verifica na Figura 7. O percentual de trabalhadores autônomos sem instrução que contribui para a previdência é 13\%. Para a faixa 16 anos ou mais de estudo, esse percentual atinge $57 \%$.

Tabela 6- Número de trabalhadores autônomos urbanos, segundo a contribuição para a previdência social, por grupos de anos de estudo, Brasil, 2013

\begin{tabular}{lccc}
\hline \multicolumn{1}{c}{ Escolaridade } & Contribui & Não contribui & Total \\
\hline Sem instrução & 131.604 & 916.268 & 1.047 .872 \\
2 a 4 anos & 170.432 & 943.277 & 1.113 .709 \\
5 a 8 anos & 805.777 & 2.748 .883 & 3.554 .660 \\
9 a 11 anos & 746.531 & 2.149 .440 & 2.895 .971 \\
12 a 15 anos & 1.538 .027 & 3.047 .801 & 4.585 .828 \\
16 anos ou mais & 790.072 & 602.649 & 1.392 .721 \\
\hline Fonte: Elaborada pelo autor a partir dos dados do IBGE (INSTITUTO BRASILEIRO DE GEOGRAFIA \\
E ESTATÍSTICA, 2014).
\end{tabular}




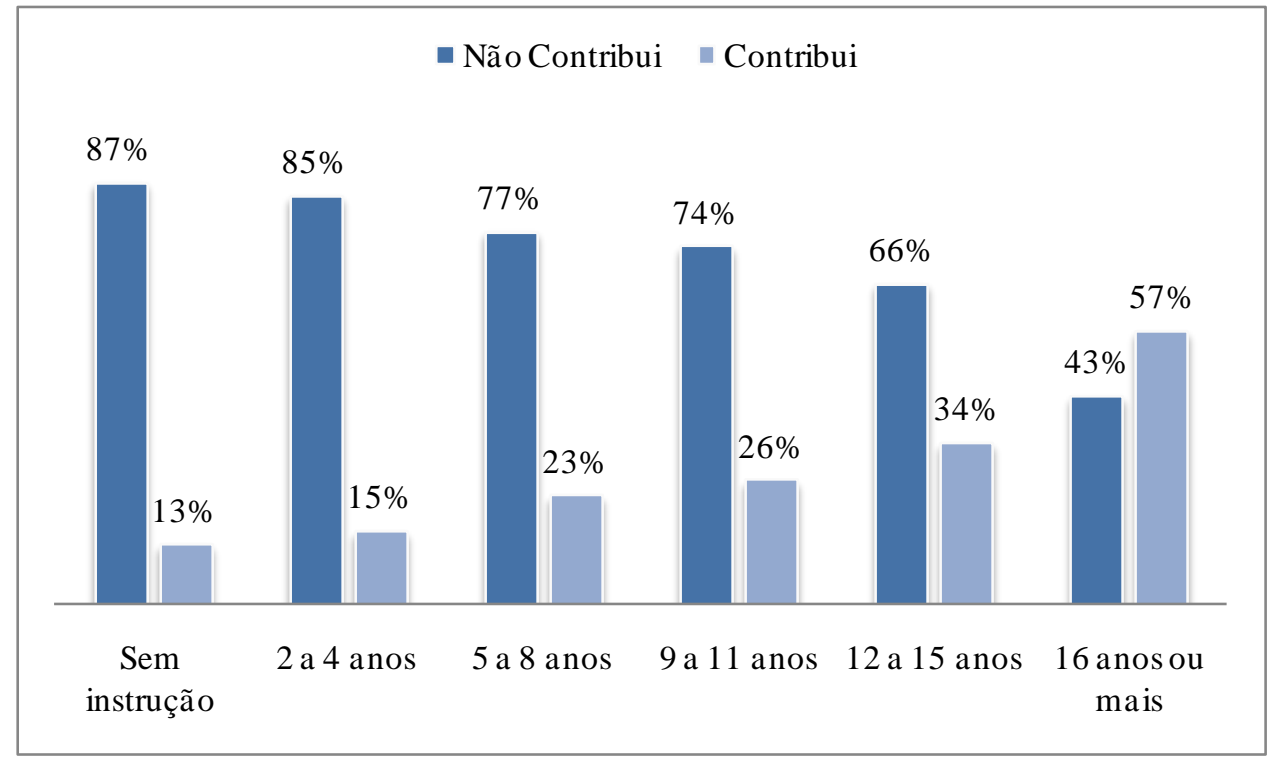

Figura 7 - Percentual de trabalhadores autônomos urbanos contribuintes para a previdência social, por grupos de anos de estudo, Brasil, 2013

Fonte: Elaborada pelo autor a partir dos dados do IBGE (INSTITUTO BRASILEIRO DE GEOGRAFIA E ESTATÍSTICA, 2014).

Em termos de distribuição dentro das regiões brasileiras, a maior parte dos trabalhadores autônomos trabalha nas regiões nordeste e sudeste (Tabela 7). O percentual de autônomos contribuintes para a previdência é maior nas regiões sul (46\%) e sudeste $(36 \%)$ e menor nas regiões nordeste $(16 \%)$ e norte $(10 \%)$, conforme mostra a Figura 8.

Tabela 7- Número de trabalhadores autônomos urbanos, segundo a contribuição para a previdência social, por grandes regiões, Brasil, 2013

\begin{tabular}{lccc}
\hline \multicolumn{1}{c}{ Região } & Contribui & Não contribui & Total \\
\hline Sul & 884.078 & 1.057 .709 & 1.941 .787 \\
Sudeste & 2.268 .848 & 3.996 .479 & 6.265 .327 \\
Nordeste & 627.336 & 3.337 .370 & 3.964 .706 \\
Centro-oeste & 271.562 & 827.409 & 1.098 .971 \\
Norte & 136.412 & 1.219 .258 & 1.355 .670 \\
\hline
\end{tabular}

Fonte: Elaborada pelo autor a partir dos dados do IBGE (INSTITUTO BRASILEIRO DE GEOGRAFIA E ESTATÍSTICA, 2014). 


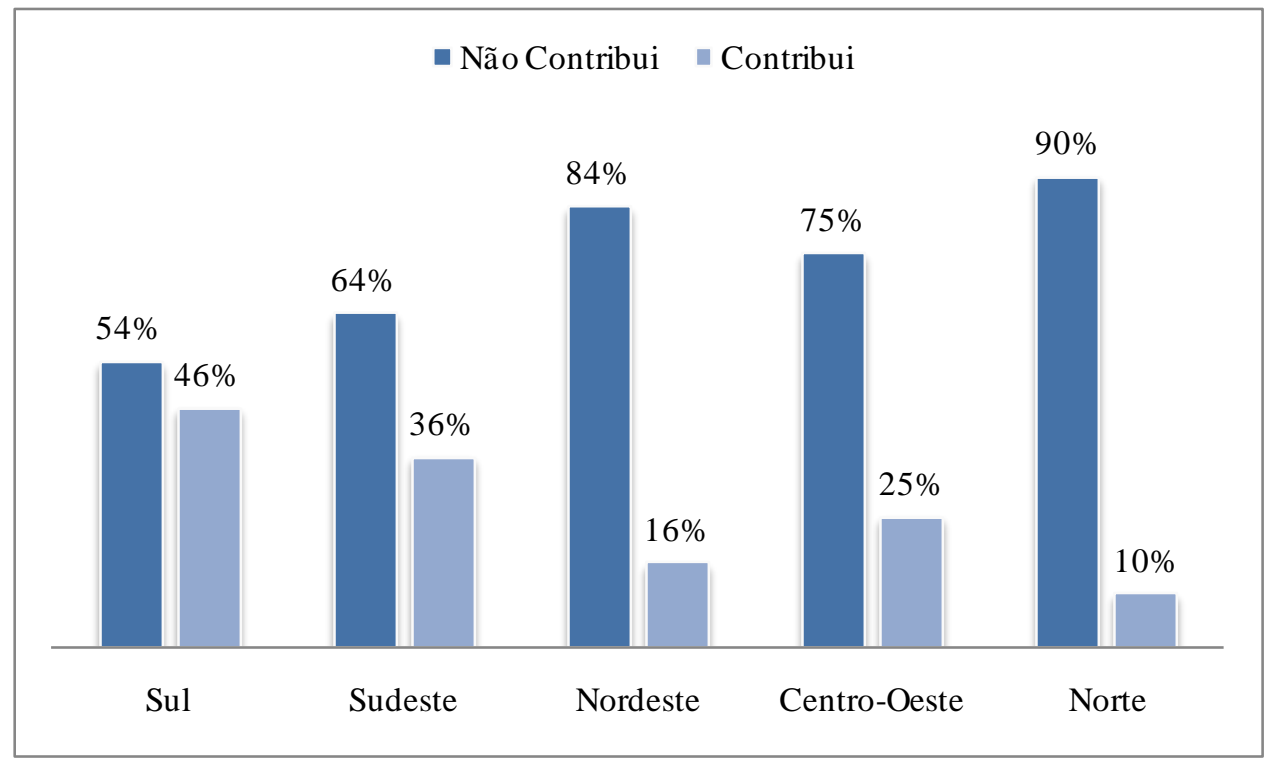

Figura 8 - Percentual de trabalhadores autônomos urbanos contribuintes para a previdência social, por grandes regiões, Brasil, 2013

Fonte: Elaborada pelo autor a partir dos dados do IBGE (INSTITUTO BRASILEIRO DE GEOGRAFIA E ESTATÍSTICA, 2014).

A Tabela 8 mostra que há uma maior concentração de autônomos que aufere renda entre um a dois salários mínimos. O percentual de autônomos que contribui para a previdência tende a crescer com a renda até certo nível e depois decresce. Entre os que ganham menos de um salário mínimo, apenas $8 \%$ contribui. Para a faixa de renda 20 a 30 salários mínimos, $72 \%$ contribui. Dos autônomos que recebem acima de 30 salários mínimos, a proporção dos que contribuem cai para 38\%, segue Figura 9.

Tabela 8 - Número de trabalhadores autônomos urbanos, segundo a contribuição para a previdência social, por classes de renda, Brasil, 2013 (em salários mínimos de 2013²)

\begin{tabular}{lccc}
\hline \multicolumn{1}{c}{ Renda } & Contribui & Não contribui & Total \\
\hline menos de 1 & 268.459 & 3.246 .684 & 3.515 .143 \\
1 a 2 & 1.133 .276 & 3.910 .044 & 5.043 .320 \\
2 a 4 & 1.382 .717 & 2.067 .341 & 3.450 .058 \\
4 a 8 & 829.620 & 615.122 & 1.444 .742 \\
8 a 12 & 172.361 & 94.033 & 266.394 \\
12 a 20 & 93.265 & 42.347 & 135.612 \\
20 a 30 & 39.792 & 15.122 & 54.914 \\
mais de 30 & 268.746 & 447.532 & 716.278 \\
\hline Fonte: Elaborada pelo autor a partir dos dados do IBGE (INSTITUTO BRASILEIRO DE GEOGRAFIA \\
E ESTATÍ́STICA, 2014). \\
${ }^{1}$ Salário mínimo vigente entre 01/01/2013 e 31/12/2013 (R \$ 678,00).
\end{tabular}




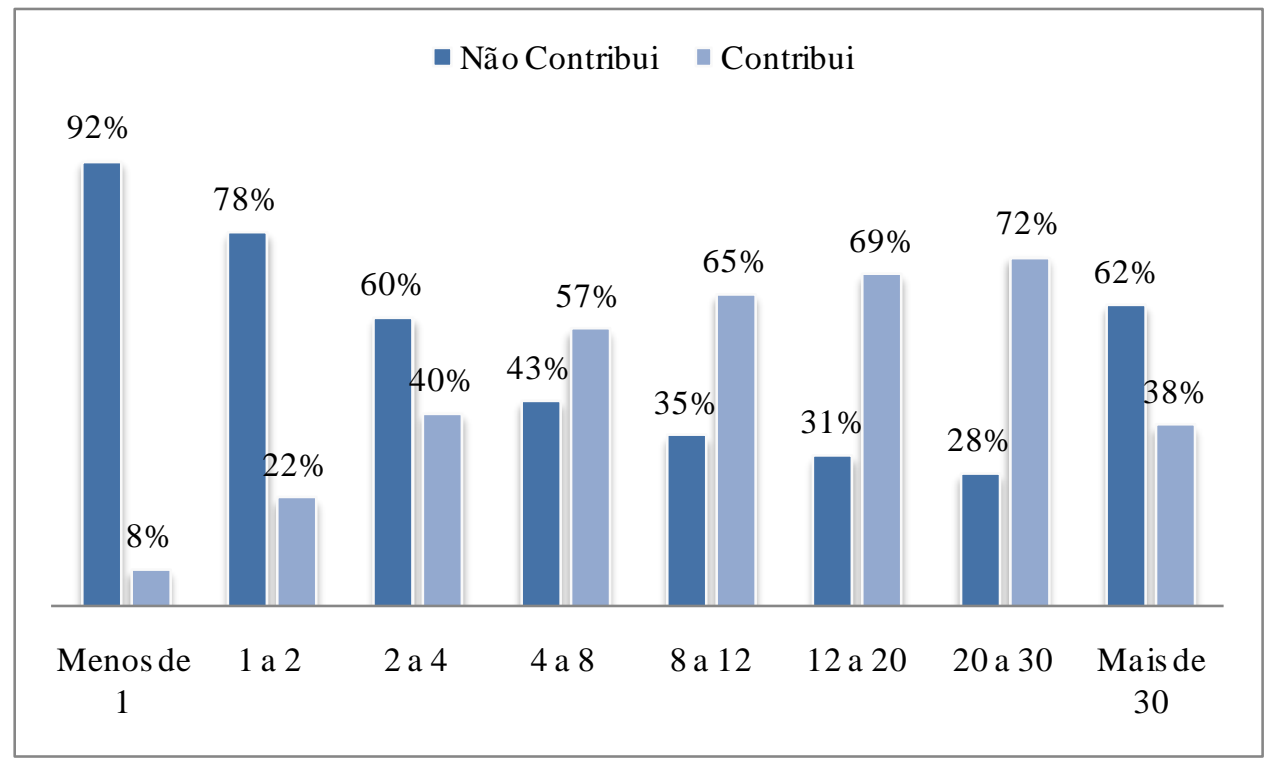

Figura 9 - Percentual de trabalhadores autônomos urbanos contribuintes para a previdência social, por classes de renda, Brasil, 2013

Fonte: Elaborada pelo autor a partir dos dados do IBGE (INSTITUTO BRASILEIRO DE GEOGRAFIA E ESTATÍSTICA, 2014).

A maioria dos trabalhadores autônomos exerce atividade na construção civil e no comércio e reparação (Tabela 9). Dos autônomos envolvidos com outras atividade industriais (extração de carvão, petróleo, gás natural, minerais metálicos e nãometálicos etc.) $90 \%$ não contribuem para a previdência. O grupo de atividade mais formal da economia é o de outras atividades, o qual envolve serviços de intermediação financeira, aluguel, atividades de informática etc. (Figura 10). 
Tabela 9 - Número de trabalhadores autônomos urbanos, segundo a contribuição para a previdência social, por grupo de atividade econômica, Brasil, 2013

\begin{tabular}{lccc}
\hline \multicolumn{1}{c}{ Grupo de atividade } & Contribui & Não contribui & Total \\
\hline Outras atividades & 2.191 & 18.841 & 21.032 \\
industriais & & & \\
Indústria de Transformação & 437.531 & 1.374 .412 & 1.811 .943 \\
Construção civil & 661.957 & 2.760 .939 & 3.422 .896 \\
Comércio e reparação & 1.161 .804 & 2.821 .349 & 3.983 .153 \\
Aloj. e alimentação & 260.112 & 750.357 & 1.010 .469 \\
Transp., armaz. e & 456.078 & 790.104 & 1.246 .182 \\
comunicação & 225.230 & 245.811 & 471.041 \\
Educ., saúde e serv. sociais & 440.389 & 1.126 .938 & 1.567 .327 \\
Outros serviços $^{2}$ & 542.944 & 549.474 & 1.092 .418 \\
Outras atividades $^{3}$ & &
\end{tabular}

Fonte: Elaborada pelo autor a partir dos dados do IBGE (INSTITUTO BRASILEIRO DE GEOGRAFIA E ESTATÍSTICA, 2014).

${ }^{1}$ Envolve as atividades de extração de carvão, petróleo, gás natural, minerais metálicos e não-metálicos; produção e distribuição de eletricidade, gás e água quente; e captação, tratamento e distribuição de água.

2 Envolve as atividades de limpeza urbana e esgoto (e atividades conexas); atividades associativas; atividades recreativas, culturais e desportivas; e serviços pessoais.

${ }^{3}$ Envolve as atividades de intermediação financeira, exclusive seguros e previdência privada; seguros e previdência privada; atividades auxiliares da intermediação financeira; atividades imobiliárias; aluguel de veículos, máquinas e equipamentos sem condutores ou operadores e de objetos pessoais e domésticos; atividades de informática e conexas; pesquisa e desenvolvimento das ciências sociais e humanas; serviços prestados principalmente às empresas; e organismos internacionais e outras instituições extraterritoriais.

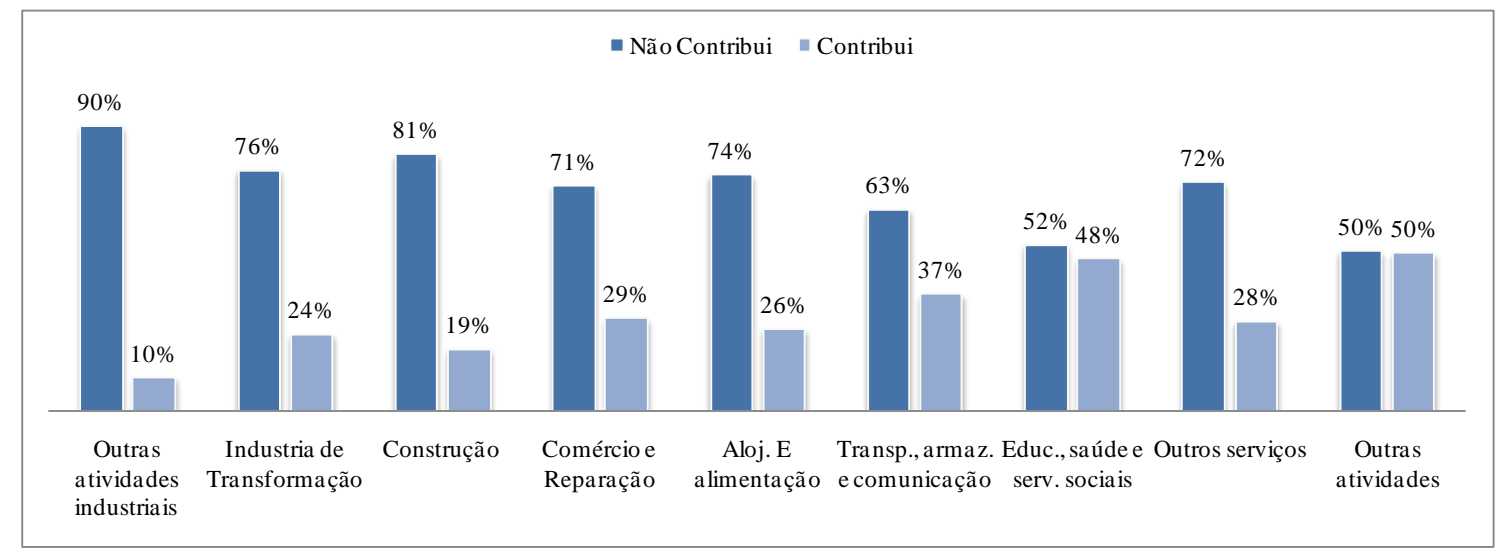

Figura 10 - Percentual de trabalhadores autônomos urbanos contribuintes para a previdência social, por grupo de atividade, Brasil, 2013

Fonte: Elaborada pelo autor a partir dos dados do IBGE (INSTITUTO BRASILEIRO DE GEOGRAFIA E ESTATÍSTICA, 2014).

Os domicílios dos trabalhadores autônomos são compostos, em sua maioria, por 3 a 4 indivíduos, conforme mostra a Tabela 10. É interessante notar que o percentual de autônomos que contribui para a previdência é menor nos grupos dos que vivem em domicílios com mais pessoas. A Figura 11revela que de $31 \%$ dos autônomos que vivem 
em domicílios com 1 a 2 pessoas contribui, contra $8 \%$ dos que vivem em domićlíos com 9 ou mais pessoas.

Tabela 10 - Número de trabalhadores autônomos urbanos, segundo a contribuição para a previdência social, por composição domiciliar, Brasil, 2013

\begin{tabular}{cccc}
\hline Comp. no domicilio & Contribui & Não contribui & Total \\
\hline 1 a 2 & 1.166 .531 & 2.593 .253 & 3.759 .784 \\
3 a 4 & 2.361 .849 & 5.281 .132 & 7.642 .981 \\
5 a 8 & 643.341 & 2.379 .711 & 3.023 .052 \\
9 ou mais & 16.515 & 184.129 & 200.644 \\
\hline
\end{tabular}

Fonte: Elaborada pelo autor a partir dos dados do IBGE (INSTITUTO BRASILEIRO DE GEOGRAFIA E ESTATÍSTICA, 2014).

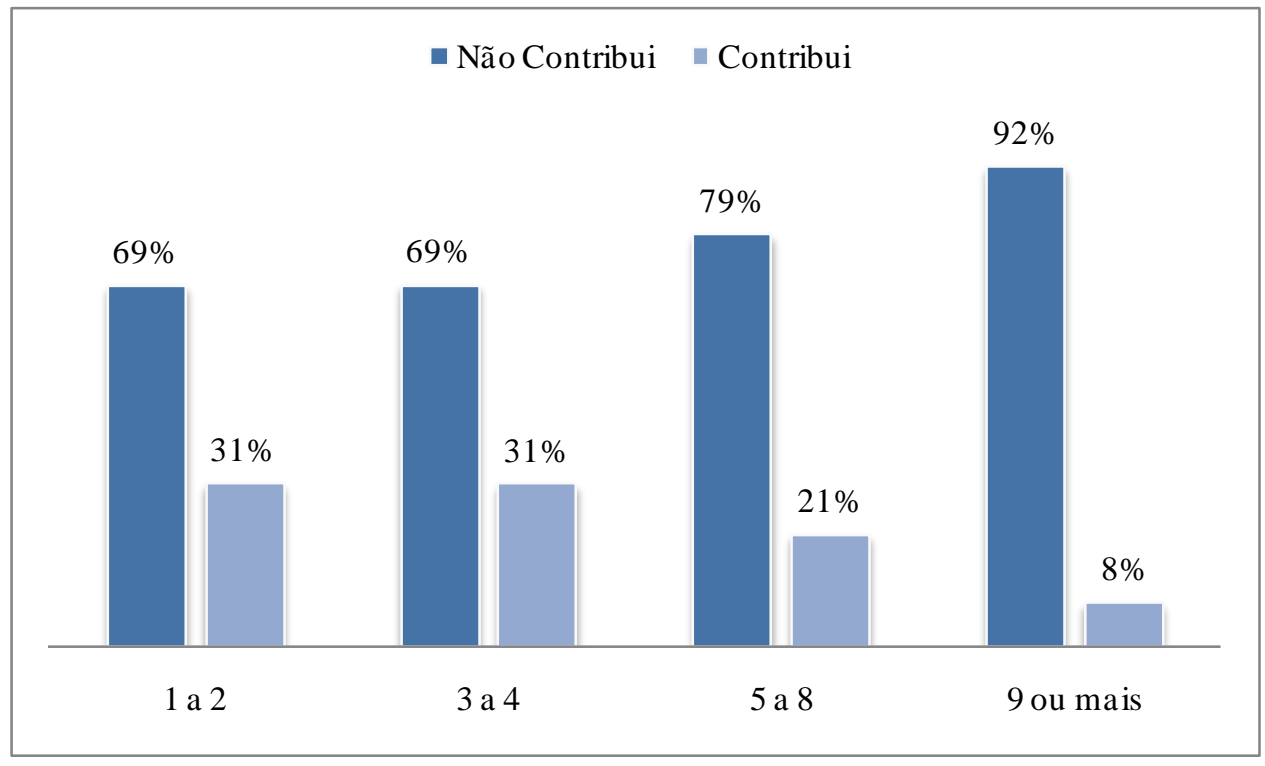

Figura 11 - Percentual de trabalhadores autônomos urbanos contribuintes para a previdência social, por composição domiciliar, Brasil, 2013

Fonte: Elaborada pelo autor a partir dos dados do IBGE (INSTITUTO BRASILEIRO DE GEOGRAFIA E ESTATÍSTICA, 2014).

\subsection{Efeitos das características socioeconômicas e demográficas dos trabalhadores autônomos sobre sua decisão de contribuir para a previdência social}

Na Tabela 11 são apresentados os coeficientes estimados da equação que explica a contribuição previdenciária dos "outros autônomos" e os respectivos desvios padrão. Os coeficientes foram, em sua maioria, estatisticamente diferentes de zero a um nível de $1 \%$ de significância pelo teste $\mathrm{z}$, indicando que as variáveis independentes são capazes de explicar a opção pela contribuição previdenciária dos trabalhadores autônomos. 
Como os parâmetros estimados do modelo logit não representam diretamente o efeito das variáveis explicativas sobre a probabilidade de contribuir para a previdência, apresentam-se também os coeficientes marginais e seus desvios padrão nas duas últimas colunas da Tabela 11. A amostra dos outros autônomos é representada por 24.047 observações.

Havia a possibilidade de algumas variáveis serem correlacionadas, prejudicando as estimações: escolaridade, rendimento e idade. Os testes de correlação apresentaram os seguintes valores: escolaridade e rendimento $(0,21)$; escolaridade e idade $(-0,25)$; e idade e rendimento $(0,08)$. Como as correlações são baixas, não há problemas em manter as três variáveis no modelo estimado. 
Tabela 11-Coeficientes estimados da equação que explica a contribuição previdenciária dos "outros autônomos"

\begin{tabular}{|c|c|c|c|c|c|}
\hline \multicolumn{2}{|c|}{ Variáveis } & \multirow{2}{*}{$\frac{\text { Coeficiente }}{-5,214 * * *}$} & \multirow{2}{*}{$\begin{array}{c}\begin{array}{c}\text { Desvio } \\
\text { padrão }\end{array} \\
0,242\end{array}$} & \multirow{2}{*}{$\begin{array}{c}\text { Efeito } \\
\text { Marginal } \\
-\end{array}$} & \multirow{2}{*}{$\begin{array}{c}\text { Desvio } \\
\text { padrão } \\
-\end{array}$} \\
\hline Constante & & & & & \\
\hline Sexo & Homem & $0,135 * *$ & 0,461 & $0,022 * *$ & 0,007 \\
\hline Idade & & $0,122 * * *$ & 0,010 & $0,030 * * *$ & 0,001 \\
\hline Idade ao quadrado & & $-0,001 * * *$ & 0 & - & - \\
\hline Escolaridade & & $0,075 * * *$ & 0,005 & $0,013 * * *$ & 0,001 \\
\hline Renda (R\$) & & $0,0005^{* * *}$ & 0 & $0,0004 * * *$ & 0 \\
\hline \multirow[t]{8}{*}{ Renda ao quadrado } & & $-1,93 \mathrm{E}-09 * * *$ & $5,15 \mathrm{E}-09$ & - & - \\
\hline & Construção civil & $-0,347 * * *$ & 0,747 & $-0,056$ *** & 0,011 \\
\hline & $\begin{array}{l}\text { Comércio e } \\
\text { reparação }\end{array}$ & $0,205^{* *}$ & 0,065 & $0,036 * *$ & 0,011 \\
\hline & Aloj. e alimentação & 0,139 & 0,093 & 0,024 & 0,017 \\
\hline & $\begin{array}{l}\text { Transp., armaz. e } \\
\text { comunicação }\end{array}$ & $0,345 * * *$ & 0,085 & $0,063 * * *$ & 0,016 \\
\hline & $\begin{array}{c}\text { Educ., saúde e serv. } \\
\text { Sociais }\end{array}$ & $-0,255$ & 0,173 & $-0,040$ & 0,025 \\
\hline & Outros serviços $^{1}$ & $0,220 * *$ & 0,079 & $0,039 * *$ & 0,014 \\
\hline & Outras atividades $^{2}$ & $-0,074$ & 0,123 & $-0,012$ & 0,020 \\
\hline \multirow{4}{*}{ Região } & Norte & $-1,482 * * *$ & 0,066 & $-0,177 * * *$ & 0,006 \\
\hline & Sul & $0,460 * * *$ & 0,058 & $0,086 * * *$ & 0,086 \\
\hline & Centro-Oeste & $-0,552 * * *$ & 0,067 & $-0,126 * * *$ & 0,008 \\
\hline & Nordeste & $-0,816^{* * *}$ & 0,054 & $-0,126^{* * *}$ & 0,007 \\
\hline $\begin{array}{l}\text { Componentes no } \\
\text { domicílio }\end{array}$ & & $-0,037 * *$ & 0,013 & $-0,006^{* *}$ & 0,002 \\
\hline $\mathrm{F}$ & 0 & & & & \\
\hline $\operatorname{Prob}(\mathrm{Y}=1)$ & 21,9 & & & & \\
\hline N. de observações & 24.047 & & & & \\
\hline
\end{tabular}

Fonte: Resultados da pesquisa.

Notas: $* * *$ significativo a $1 \%$; ** significativo a $5 \%$; $*$ significativo a $10 \%$.

${ }^{1}$ Envolve as atividades de limpeza urbana e esgoto (e atividades conexas); atividades associativas; atividades recreativas, culturais e desportivas; e serviços pessoais.

${ }^{2}$ Envolve as atividades de intermediação financeira, exclusive seguros e previdência privada; seguros e previdência privada; atividades auxiliares da intermediação financeira; atividades imobiliárias; aluguel de veículos, máquinas e equipamentos sem condutores ou operadores e de objetos pessoais e domésticos; atividades de informática e conexas; pesquisa e desenvolvimento das ciências sociais e humanas; serviços prestados principalmente às empresas; e organismos internacionais e outras instituições extraterritoriais.

Os resultados mostram que os "outros autônomos" urbanos brasileiros, maiores de 16 anos e não aposentados têm, em média, 21,9\% de probabilidade de contribuir para a previdência social. Os homens apresentam, em média, maior probabilidade de contribuir para a previdência social em relação às mulheres $(2,2$ pontos percentuais a mais, conforme o valor do efeito marginal). Esse resultado indica, provavelmente, que a desigualdade de emprego e renda entre homens e mulheres afeta a procura pela previdência. Mulheres têm maiores dificuldades de adquirir emprego e renda, consequentemente, as possibilidades de contribuir para previdência social são menores. 
Esse resultado foi apontado por Loke e Goh (2012) em um estudo sobre a identificação dos fatores que impulsionam a demanda por seguro na Malásia.

O sinal do coeficiente da variável idade é positivo, demonstrando que quanto maior a idade, maior a probabilidade de o autônomo contribuir para a previdência, indicando que a demanda pela previdência desses trabalhadores tende aumentar à medida que ficam mais velhos. Contudo, a probabilidade não cresce infinitamente com a idade. $\mathrm{O}$ coeficiente negativo da variável idade ao quadrado revela que a propensão a contribuir aumenta até certa idade (61 anos) e depois passa a decrescer. Estes dados corroboram os resultados do estudo de Palsson (1996).

Quanto maior a escolaridade do trabalhador autônomo (em anos de estudo), maior é sua consciência sobre o risco de perda de rendimentos por doença, velhice etc., e maior as chances de ele contribuir para a previdência social. Cada ano a mais de estudo aumenta a probabilidade de contribuir em 1,3 pontos percentuais. À medida que a aumenta a instrução do autônomo, aumenta o conhecimento. A escolaridade fornece maior autocrítica, o autônomo torna-se mais capaz de reconhecer a importância da previdência social, além de saber que a contribuição gera proteção e seguro contra acidentes, mortes, doenças, entre outros. De acordo Outreville (2013), que fez uma revisão de literatura sobre demanda por seguro, a escolaridade pode afetar positivamente ou negativamente a aversão ao risco, dependendo do nível de instrução escolhido pelo autor.

O coeficiente da variável renda é positivo e o da variável renda ao quadrado é negativo, indicando que a probabilidade de contribuir para a previdência cresce com o aumento dos rendimentos mensais até certo ponto $(\mathrm{R} \$ 14.602,04)$ e depois tende a cair. Esse resultado indica, provavelmente, que trabalhadores com pequenos rendimentos têm necessidades mais urgentes para cobrir (gastos com alimentação, aluguel, energia elétrica, água etc.), tendo que abrir mão da contribuição previdenciária. Os trabalhadores com níveis elevados de renda, por outro lado, deixam de contribuir para a previdência social por terem outras formas de se prevenir contra eventuais perdas de rendimentos via aplicações no mercado financeiro, previdência privada, aquisição de imóveis etc. Além disso, o valor de contribuição passa a ser elevado para níveis de renda mais altos (20\% sobre o salário de contribuição). Um autônomo que queira contribuir sobre uma renda mensal de $\mathrm{R} \$ 10$ mil, por exemplo, deve arcar com um custo mensal de R\$ 2 mil por mês. Estes resultados são semelhantes aos encontrados por Calvet, Campbell e Sodini (2006), que investigaram a eficiência das decisões de 
investimento das famílias em um conjunto de dados que contém a riqueza desagregada e a renda de toda população da Suécia. O efeito marginal mostra que a renda é um importante determinante da contribuição previdenciária dos trabalhadores autônomos: cada $\mathrm{R} \$ 100,00$ a mais de renda aumenta a probabilidade de contribuir em 4 pontos percentuais.

Os trabalhadores do setor construção civil, têm, em média, 34,7 pontos percentuais a menos de probabilidade de contribuir para a previdência social que os da indústria de transformação (o grupo de referência), estatisticamente falando. Os autônomos que exercem atividades de transporte, armazenagem e comunicação e comércio e reparação, e outros serviços têm maior probabilidade de contribuir que os do grupo de referência. Os trabalhadores do alojamento e alimentação, educação, saúde e serviços sociais, e outras atividades têm, estatisticamente, a mesma probabilidade de contribuir que os da indústria de transformação. Maior taxa de contribuição previdenciária da indústria de transformação pode ser compreendida por ser um setor que tradicionalmente regulariza suas atividades.

A análise dos parâmetros associados às variáveis binárias para as regiões brasileiras mostra que os autônomos das regiões com maior dinamismo econômico possuem maiores chances de contribuir para a previdência. Verifica-se que os trabalhadores da região Sul têm maior probabilidade para contribuir que os da região Sudeste (grupo de referência). Já os autônomos das regiões Centro-Oeste, Nordeste e Norte são, em média, menos propensos a contribuir em relação aos da região de referência (com todas as outras variáveis mantidas constantes em seus valores médios). Os autônomos das regiões Centro-Oeste e Nordeste, por exemplo, têm em média 55,2 e 81,6 pontos percentuais a menos de probabilidade de serem contribuintes. Segundo Hersch (1996), pessoas de regiões mais desenvolvidas tanto economicamente quanto socialmente possuem maiores chances de contribuir para algum seguro. Isto significa dizer que, provavelmente, a falta de informação e os fatores culturais causam efeitos na probabilidade dos autônomos contribuírem.

Os resultados mostram ainda que quanto maior o número de pessoas no domicílio, menor é a probabilidade de o autônomo contribuir para a previdência (cada membro a mais reduz a probabilidade em 0,6 pontos percentuais, em média). Esse resultado corrobora o encontrado por Cubeddu e Ríos-Rull (2003). Neste artigo, os autores mostram a importância quantitativa do processo que determina mudanças na composição familiar para as principais variáveis macroeconômicas dos Estados Unidos. 
À medida que aumenta o número de pessoas no domicilio, o autônomo realoca suas contas, cobrindo as obrigações mais urgentes.

Na Tabela 12são apresentados os coeficientes estimados da equação que explica a contribuição previdenciária dos "profisssionais liberais" e os respectivos desvios padrão, além dos efeitos marginais e seus desvios padrão. Bem semelhante aos coeficientes dos "outros autônomos", em sua maioria, os coeficientes dos "profissionais liberais" foram significativos ao nível de 1\%. A amostra dos profissionais liberais é representada por 6.741 observações.

Em relação à correlação de algumas variáveis, foram apresentados os seguintes valores: escolaridade e rendimento $(0,03)$; escolaridade e idade $(-0,39)$; e idade e rendimento $(0,21)$. Dessa maneira, também não houve problemas de manter essas três variáveis no modelo estimado.

Tabela 12- Coeficientes estimados da equação que explica a contribuição previdenciária dos "profissionais liberais"

\begin{tabular}{|c|c|c|c|c|c|}
\hline \multicolumn{2}{|c|}{ Variáveis } & \multirow{2}{*}{$\begin{array}{l}\text { Coeficiente } \\
-4,277^{* * *} \\
\end{array}$} & \multirow{2}{*}{$\begin{array}{c}\begin{array}{c}\text { Desvio } \\
\text { padrão }\end{array} \\
0,480 \\
\end{array}$} & \multirow{2}{*}{$\begin{array}{c}\begin{array}{c}\text { Efeito } \\
\text { Marginal }\end{array} \\
- \\
\end{array}$} & \multirow{2}{*}{$\begin{array}{c}\begin{array}{c}\text { Desvio } \\
\text { padrão }\end{array} \\
- \\
\end{array}$} \\
\hline Constante & & & & & \\
\hline Sexo & Homem & $0,239 * *$ & 0,116 & $0,039 * *$ & 0,018 \\
\hline Idade & & $0,091 * * *$ & 0,020 & $0,038 * * *$ & 0,004 \\
\hline Idade ao quadrado & & $-0,001 * * *$ & 0 & - & - \\
\hline Escolaridade & & $0,085 * * *$ & 0,011 & $0,014 * * *$ & 0,001 \\
\hline Renda (R\$) & & $0,0002 * * *$ & 0 & $0,0002 * * *$ & 0 \\
\hline \multirow[t]{8}{*}{ Renda ao quadrado } & & $-6,85 \mathrm{E}-09 * * *$ & $2,23 \mathrm{E}-09$ & $\overline{-}$ & - \\
\hline & Construção civil & $-0,635 * * *$ & 0,150 & $-0,114 * * *$ & 0,028 \\
\hline & $\begin{array}{l}\text { Comércio e } \\
\text { reparação }\end{array}$ & 0,052 & 0,168 & 0,009 & $0,0,29$ \\
\hline & Aloj. e alimentação & 0,320 & 0,405 & 0,059 & 0,081 \\
\hline & $\begin{array}{l}\text { Transp., armaz. e } \\
\text { comunicação }\end{array}$ & $-0,139$ & 0,308 & $-0,023$ & 0,048 \\
\hline & $\begin{array}{l}\text { Educ., saúde e serv. } \\
\text { Sociais }\end{array}$ & $0,394 * *$ & 0,207 & $0,074 *$ & 0,042 \\
\hline & Outros serviços $^{3}$ & $-0,684 * *$ & 0,279 & $-0,096^{* * *}$ & 0,031 \\
\hline & Outras atividades ${ }^{4}$ & 0,147 & 0,174 & 0,026 & 0,031 \\
\hline \multirow{4}{*}{ Região } & Norte & $-1,424 * * *$ & 0,126 & $-0,170 * * *$ & 0,011 \\
\hline & Sul & $0,429 * * *$ & 0,102 & $0,079 * * *$ & 0,020 \\
\hline & Centro-Oeste & $-0,759$ *** & 0,131 & $-0,107 * * *$ & 0,015 \\
\hline & Nordeste & $-0,743 * * *$ & 0,100 & $-0,113 * * *$ & 0,013 \\
\hline $\begin{array}{c}\text { Componentes no } \\
\text { domicílio }\end{array}$ & & $-0,049 * *$ & 0,023 & $-0,008 * *$ & 0,004 \\
\hline $\mathrm{F}$ & 0 & & & & \\
\hline Prob $(Y=1)$ & 22 & & & & \\
\hline N. de observações & 6.741 & & & & \\
\hline
\end{tabular}


Fonte: Resultados da pesquisa.

Notas: $* * *$ significativo a $1 \%$; $* *$ significativo a $5 \%$; significativo a $10 \%$.

${ }^{1}$ Envolve as atividades de limpeza urbana e esgoto (e atividades conexas); atividades associativas; atividades recreativas, culturais e desportivas; e serviços pessoais.

${ }^{2}$ Envolve as atividades de intermediação financeira, exclusive seguros e previdência privada; seguros e previdência privada; atividades auxiliares da intermediação financeira; atividades imobiliárias; aluguel de veículos, máquinas e equipamentos sem condutores ou operadores e de objetos pessoais e domésticos; atividades de informática e conexas; pesquisa e desenvolvimento das ciências sociais e humanas; serviços prestados principalmente às empresas; e organismos internacionais e outras instituições extraterritoriais.

Os resultados mostram que o "profissional liberal" urbano brasileiro, maior de 16 anos e não aposentado têm, em média, $22 \%$ de probabilidade de contribuir para a previdência social. Todos os sinais desse modelo são iguais ao modelo dos "outros autônomos", porém, relativamente, as chances de contribuição do modelo dos "profissionais liberais", em sua maioria, são maiores. Apenas o resultado da variável idade mostrou que as chances de contribuição do profissional liberal é menor do que os demais trabalhadores autônomos.

É importante notar que as chances de contribuição dos profissionais liberais é quase o dobro dos outros autônomos, em relação ao sexo. Este apresenta 1,7 pontos percentuais a menos daquele, conforme o valor do efeito marginal. Indicando que a diferença de contribuição é ainda maior quando comparado à posição de ocupação entre homens e mulheres.

Embora o nível de escolaridade traga maior conscientização para os profissionais liberais, a contribuição previdenciária desses é bem parecida com a dos demais autônomos. O coeficiente apresentado pelos outros autônomos é 0,075 e dos profissionais liberais é 0,085 . Esses resultados indicam que à medida que aumenta a escolaridade, aumentam as chances de contribuição, no entanto, comparativamente, a diferença entre eles é pequena.

Comparando o profissional liberal e outros autônomos na construção civil, o primeiro tem 5,8 pontos percentuais a mais de chances de contribuir para previdência social em relação ao segundo.

No que se refere à região que reside o trabalhador autônomo, centro-oeste apresentou maiores diferenças de probabilidade de contribuir para previdência social. Os outros autônomos têm probabilidade de contribuição de $-0,552$ e os profissionais liberais têm de $-0,743$. 


\section{CONCLUSÃO}

Um dos objetivos da previdência social é proteger os trabalhadores e seus familiares contra os riscos de perda de capacidade laboral causados por acidentes, doenças, velhice, morte etc. Ela atua como um seguro que visa resguardar o trabalhador contra as incertezas que o cercam.

No Brasil, os empregados com carteira de trabalho assinada e os funcionários públicos contribuem compulsoriamente para esse seguro. Outros trabalhadores, como os empregados sem carteira assinada, podem escolher contribuir ou não para previdência social.

Este trabalho analisou em que magnitude certos fatores socioeconômicos e demográficos(gênero, idade, escolaridade, renda, grupo de atividade econômica, região de residência e número de componentes no domicilio) influenciam na probabilidade de os trabalhadores autônomos contribuir para a previdência social.

Dos autônomos, somente 29\% contribuem para a previdência social. Os resultados deste estudo mostraram que a renda dos trabalhadores tem um importante efeito sobre a probabilidade de contribuir para a previdência. Existe um alto custo de oportunidade para contribuir para previdência social, pois o sistema precário de crédito faz com que a poupança se torne um bem de luxo.

Verificou-se que os profissionais liberais (autônomos que exercem atividades mais bem organizadas e formais) apresentam maior probabilidade de contribuir para a previdência que os demais trabalhadores autônomos. Contudo, as chances de contribuir para previdência social é mais intensa para os profissionais liberais.

Por último, observou-se que a probabilidades de contribuir para a previdência é maior entre as pessoas mais escolarizadas, que provavelmente são mais bem informadas sobre os benefícios da previdência. A falta de informação dos trabalhadores é um dos principais desafios que a previdência social precisa vencer.

Dessa forma, o grande desafio da previdência social brasileira é atrair o contingente de não-contribuintes com políticas mais específicas, levando em conta a heterogeneidade do trabalho autônomo. Neste sentido, a contribuição do presente trabalho consiste em mostrar como as características socioeconômicas afetam a escolha dos trabalhadores que contribuem para previdência dos que não contribuem, considerando a previdência social como uma espécie de seguro. Além disso, evidencia-a 
decisão de ser trabalhador autônomo (ora por opção ora por exclusão), separando o profissional liberal dos demais trabalhadores autônomos.

Por fim, sugere-se que novos estudos possam ser implementados para complementar os resultados desta pesquisa. Pode-se, por exemplo, incluir na amostra outros trabalhadores que contribuem facultativamente para a previdência, como é o caso dos empregados sem carteira assinada, os empregadores, os trabalhadores que produzem para o próprio consumo e os não-remunerados. Pode-se também identificar os fatores que atraem os trabalhadores autônomos a contribuírem para previdência social. Além disso, pode-se analisar como mudanças nas regras previdenciárias(alterações de alíquotas etc.) afetam o comportamento dos trabalhadores que contribuem de modo facultativo para a previdência. 


\section{REFERÊNCIAS BIBLIOGRÁFICAS}

AARON, H. J. Economic effects of social security. Vol.16. Washington D.C. Brookings Institution Press, 1982.

ABREU, M. de P. A ordem do progresso: cem anos de política econômica republicana, 1889-1989. Editora Campus, 1989.

AFONSO, L. E. Mudanças de regimes previdenciários: existe uma transição PAYGO-FF Pareto-otima?1999. 105 f. Dissertação (Mestrado em Economia)- Curso de Pós-Graduação em Economia, FGV/Escola de Administração de Empresas de São Paulo, São Paulo, 1999.

AFONSO, L. E. Um estudo dos aspectos distributivos da previdência social no Brasil. Tese de Doutorado. 2003. 135 f. Tese (Doutorado em Economia) - Curso de Pós-Graduação em Economia, Universidade de São Paulo. São Paulo, 2003.

AFOnSO, L. E., CARVAlHO, J. V. F. Fatores Explicativos da Demanda por Seguros: Algumas Evidências do Mercado Segurador Paulista. Associação Nacional dos centros de Pós-graduação de Economia (ANPEC), 2011. Disponível em: < hppt//:www.anpec.org.br >. Acesso em: 17/01/2015.

AMADEO, E.; BARROS, R.P.; CAMARGO, J.M.; GONZAGA, G.; MENDONÇA, R. A natureza e o funcionamento do mercado de trabalho brasileiro desde 1980. IPEA, Série Seminários. 1994. Disponível em: < http://hdl.handle.net/11058/2464 >. Acesso em: 13/02/2015.

ANDRADE, M. V.; MAIA, A. C. Demanda por planos de saúde no Brasil. FG Silveira, LM Servo y otros (comps.), Gasto e consumo das famílias brasileiras contemporâneas.Vol.2, 2007. Disponível em: < http://www.ipea.gov.br/agencia/ images/stories/PDFs/livros/15_Cap08.pdf > . Acessoem: 09/12/2014.

ARIAS O. S., FARJNZYLBER, P., SAAVEDRA-CHANDUVI, J., MASON, A. D., MALONEY, A. D.Informality: exit and exclusion. World Bank, Washington, 2007.

BAHIA, L., COSTA A. J. L., FERNANDES, C., LUIZ, R. R., \& CAVALCANTI, M. D. L. Segmentação da demanda dos planos e seguros privados de saúde: uma análise das informações da PNAD/98. Ciência e. saúde coletiva, Rio de Janeiro, v. 7, n. 4, jan. 2002. Disponível em <http://www.scielosp.org/ scielo.php?script=sci_arttext\&pid=S1413-81232002000400006\&lng=pt\&nrm=iso . Acesso em: 31/03/2015.

BARR, N., DIAMOND, P. The economics of pensions. Oxford review of economic policy, v. 22, n. 1, p. 15-39, 2006.

BECK, T. WEBB, I. Economic, demographic, and institutional determinants of life insurance consumption across countries. The World Bank Economic Review 17.1 
(2003): 51-88. Disponível em: < http://siteresources.worldbank.org/ DEC/Resources/bwf.pdf $>$. Acesso em: 23/02/2015.

BELLANTE, D., GREEN, C. A. Relative risk aversion among the elderly. Reviewof Financial Economics13.3 (2004): 269-281. Disponível em: < http://www.sciencedirect.com/science/article/pii/S1058330003000703\# >. Acesso em: 09/10/2014.

BEVERIDGE, S. W. O Plano Beveridge: relatório sobre o seguro social e serviços afins. Rio de Janeiro: José Olympio.1943.

BLANCHFLOWER, D. G. Self-employment in OECD countries. Labour economics 7.5 (2000): 471-505. Disponível em: < http://www.dartmouth.edu/ blnchflr/papers/sdarticle.pdf $>$. Acesso em: 03/11/2014.

BOSCHETTI, I. Implicações da reforma da previdência na seguridade social brasileira. Psicologia \& Sociedade, Belo Horizonte, v. 15, n. 1, Jan. 2003. Disponível em: $\quad<\quad h t t p: / / w w w . s c i e l o . b r / s c i e l o . p h p ? s c r i p t=s c i \_a r t t e x t \& p i d=S 0102-$ $71822003000100005 \& \operatorname{lng}=$ en\&nrm=iso $>$. Acesso em: 02/01/2015.

BOSCHETTI, I. Seguridade social e trabalho: paradoxos na construção das políticas de previdência e assistência social no Brasil. Brasília, Letras Livres/Editora da UnB.2006.

BOSCHETTI, I. Seguridade social no Brasil: conquistas e limites à sua efetivação. Serviço Social: Direitos Sociais e Competências Profissionais. Brasília: CFESS. $2009 . \quad<\quad$ Disponível em: http://portal.saude.pe.gov.br/sites/portal.saude.pe.gov.br/files/seguridadesocialnobrasilc onquistaselimitesasuaefetivacao-boschetti.pdf $>$. Acesso em: 19/01/2015.

BRASIL. Constituição da República Federativa do Brasil de 1988. Disponível em: < http://www.planalto.gov.br/ccivil03/constituicao/Constituicao.htm >. Acesso em: 12 de dezembro de 2014.

CAMARGO, J. M. Política social no Brasil: prioridades erradas, incentivos perversos. São Paulo em perspectiva, v. 18, n. 2, p. 68-77. São Paulo, 2004.

CALVET, L. E.; CAMPBELL, J. Y.; SODINI, P.. Down or out: Assessing the welfare costs of household investment mistakes. National Bureau of Economic Research.2006.< Disponívelem: http://pzp.hhs.se/media/1422/ down\%20or\%20out\%20jpe\%202007.pdf > . Acesso em: 11/03/2015.

CONSTANT, A. ZIMMERMANN, K. F. The making of entrepreneurs in Germany: Are native men and immigrants alike?. Small business economics, v. 26, n. 3, p. 279300,2006 .

CORSEUIL, C. H; REIS, M. C. Uma definição alternativa para ocupação informal. Mercado de trabalho, v. 46, p. 30,2011. Disponível em: <http://www.en.ipea.gov.br/agencia/ images/ stories/ PDFs/ mercadodetrabalho/ bmt46_3nt02_umadefinicao.pdf $>$. Acessoem: 25/11/2014. 
CORSINI, L., PACINI, P. M., SPATARO, L. Workers' Choice on Pension Schemes A Theoretical Model and an Application to the Italian Second Pillar Reform. Public Finance Review, 2012. Disponível em: <http://www.econ.umn.edu/ vrOj/papers/ papven.pdf >. Acesso em: 24/10/2014.

CUBEDDU, L. RÍOS-RULL, J. V. Families as shocks. Journal of the Europe na Economic Association, v. 1, n 2-3, 671-682,2003. Disponível em: <http://www.econ.umn.edu/ vr0j/papers/papven.pdf>. Acesso em: 08/02/2015.

DELGADO, G. CARDOSO JR, J. C. Principais resultados da pesquisa domiciliar sobre a previdência rural na região sul do Brasil (Projeto Avaliação Socioeconômica da Previdência Social Rural).IPEA - Instituto de Pesquisa Econômica Aplicada,2000.Disponivel em: <http://hdl.handle.net/11058/2304>. Acessoem: 29/09/2014.

DIAMOND, P. A. Nationaldebt in a neoclassicalgrowthmodel. The American Economic Review, p. 1126-1150,1965.

DRAGOS, S. L. Life and non-life insurance demand: the different effects of influence factors in emerging countries from Europe and Asia.EconomicResearchEkonomskaIstraživanja, v. 27, n. 1, p. 169-180, 2014.

DRAIBE, S. M. As políticas sociais eo neoliberalismo-reflexões suscitadas pelas experiências latino-americanas. Revista USP, n 17, p. 86-101, 1993.

ESCOLA DE PÓS-GRADUAÇÃO EM ECONOMIA DA FUNDAÇÃO GETÚLIO VARGAS. Cenários de previdência social e reflexos para os fundos de pensão. Rio de Janeiro: ABRAPP. São Paulo,2002. Relatório.

FARO, C. Previdência social: cidadania e provisão. Rio de Janeiro: Escola de PósGraduação em Economia da FGV, 1992, 31 p. (Ensaios econômicos).

FERREIRA, C. R.; SOUZA, S. de CI de. Aposentadorias e pensões e desigualdade da renda: uma análise para o Brasil no período 1998-2003. Revista de Economia Contemporânea, v. 12, n. 1, p. 41-66, 2008. Disponível em: <http://www.ie.ufrj.br/ images/blog/REC_12.1_02_Aposentadorias-e-pensoes-e-esigualdade-darenda.pdf>.Acessoem: 11/02/2014.

FRIEND, I.; BLUME, M. E.The demand for risky assets. The American Economic Review.Vol. 65, n. 5, p. 900-922, 1975.Disponível em: <http://www.jstor.org/stable/1806628?seq=1\#page_scan_tab_contents>. Acesso em: 07/07/2014.

FUNDAÇÃO DE ECONOMIA E ESTATÍSTICA. A Politica Social Brasileira 193064: evolução institucional do Brasil e do Rio Grande do Sul. Porto Alegre, Fundaçãode Economia e Estatística,1983. Relatório. 
FUNDAÇÃO INSTITUTO DE PESQUISAS ECONÔMICAS. Proposta FIPE/PROSEG para a reforma da seguridade e da previdência social.São Paulo: FIPE,1993, 116 p. (Versão para debate).

GALEAZZI, I. M. S.. O trabalhador por conta própria na RMPA. Indicadores Econômicos FEE, v. 22, n. 2, p. 165-180, 1994. Disponível em: <http://revistas.fee.tche.br/index.php/indicadores/article/view/828>.Acesso em: 10/06/2014.

GIAMBIAGI, F.; BARBOSA, F. O ajuste fiscal de 1990-93: uma análise retrospectiva. Revista Brasileira de Economia, v. 49, n. 3, p. 521-544, 1995.

GIAMBIAGI, F. DE ALÉM, A. C. Duarte. Finanças públicas: teoria e prática no Brasil.4. Ed. Rio de janeiro:Elsevier Brasil. 2008.

GONÇALVES, M. A. Informalidade e precarização do trabalho no Brasil. Revista Pegada, $\quad$ v. $3,2011 . \quad$ Disponível em: <http://revista.fct.unesp.br/index.php/pegada/article/viewArticle/790>. Acessoem: $10 / 10 / 2014$.

GREENE, W. H.; Econometrics Analysis. 6. Ed. New Jersey: Pearson Education, 2008 .

HERSCH, J.. Smoking, Seat Belts, and Other Risky Consumer Decisions: Differences by. Managerial and Decision Economics, v. 17, p. 471-481, 1996.Disponívelem: <http://law.vanderbilt.edu/files/archive/1996_Hersch_Smoking-Seat-Belts-GenderRace-MDE-Sep-Oct-96.pdf>. Acesso em: 12/11/2014.

HIRATA, G. I.; MACHADO, A. F.. Conceito de informalidade/formalidade e uma proposta de tipologia. Mercado de trabalho, v. 34, p. 23, 2007.

HOLZMANN, L. O Trabalhador por Conta Própria no Brasil. Revista Paranaense de Desenvolvimento-RPD, v. 34, n. 124, p. 119-137, 2013.

HUJO, K. Novos paradigmas na previdência social: lições do Chile e da Argentina. Planejamento e Políticas Públicas, n. 19, 2009. Disponível em: <http://www.ipea.gov.br/ppp/index.php/PPP/article/viewFile/92/97>. Acessoem: $13 / 11 / 2014$.

HWANG, T. GAO, S.Thedeterminantsofthedemand for lifeinsurance in anemergingeconomy-the case of China. Managerial Finance.V.29 n. 5/6, p. 82-96, 2003.

INSTITUTO BRASILEIRO DE GEOGRAFIA E ESTATÍSTICA (IBGE).Pesquisa Nacional por Amostra de Domicílios (PNAD). 2013.

INSTITUTO DE PESQUISA ECONÔMICA APLICADA (IPEA). Boletim de políticas sociais- acompanhamento e análise. Rio de Janeiro, n. 13, edição especial, 2007.Relatório. 
KAPLAN, D. S.; LEVY, S. The Evolutionof Social Security Systems in Latin America. Social Insurance, Informality, and Labor Markets: How to Protect Workers While Creating Good Jobs. Inglaterra, 2014.Relatório.

LAZZAROTTO, J. J.; COSTA, T. M. T.; SANTOS, M. L. Risco e incerteza. In: SANTOS, M. L.; LÍRIO, V. S.; VIEIRA, W. C. Microeconomia aplicada. Visconde do Rio Branco: Suprema, 2009.

LOKE, Y. J; GOH, Y. Y. Demand for Life Insurance in Malaysia .International Proceedings of Economics Development \& Research, v. 43, 2012. Disponível em: <http://rfs.oxfordjournals.org/content/23/1/385.short>.Acesso em: 22/01/2015.

LOVE, D. A. The effects of marital status and children on savings and portfolio choice. Review of Financial Studies, v. 23, n. 1, p. 385-432, 2010.Disponível em: <http://rfs.oxfordjournals.org/content/23/1/385.short>. Acesso em: 03/12/2014.

MARQUES, R. M.et al. A previdência social no Brasil. Direção Executiva da CNTE, 2003 .

MAIA, A. C., ANDRADE, M. V., OLIVEIRA, A. M. H. C. O risco moral no sistema de saúde suplementar brasileiro. In: ENCONTRO NACIONAL DE ECONOMIA, 32 ., João Pessoa, 2004.Anais... João Pessoa: ANPEC, 2004. p. 1-21.

MACHADO, A. F.; ANDRADE, M. V. Qualificação do excedente de mão-de-obra: estratégia de vida dos trabalhadores por conta própria. In: ENCONTRO NACIONAL DE ECONOMIA, 22 , Florianópolis, 1994. Anais...FlorianópolisSC: ANPEC: 1994.

MACHADO, A. F.; OLIVEIRA, A. M. H. C.; ANTIGO, M. Evolução do diferencial de rendimentos entre setor formal e informal no Brasil: o papel das características não observadas.Revista de Economia Contemporânea, v. 12, n. 2, p. 355-388, 2008. Disponível em: <http://www.anpec.org.br/encontro2006/artigos/A06A021.pdf.>Acessoem: 25/09/2015.

MAS-COLELL A., WHINSTON M. D. e GREEN J. R. Microeconomic Theory. Oxford University Press.Nova York, 1995.

MEDEIROS, M. A trajetória do WelfareState no Brasil: papel redistributivo das políticas sociais dos anos 1930 aos anos 1990. IPEA (INSTITUTO DE PESQUISA ECONÔMICA). 2001. Texto para Discussão n. 852. Disponível em: <http://www.ipea.gov.br/portal/images/stories/PDFs/TDs/td_0852.pdf>. Acesso em: 22/01/2015.

MELGUIZO, Á., BOSCH, M., PAGÉS. C. Melhores aposentadorias, melhores trabalhos: Em direção à cobertura universal na América Latina e no Caribe.1. Ed. Banco Interamericano de Desenvolvimento (BID), 2013.

MENEZES, W. F., CRUZ, J. V. B. O trabalho autônomo na estrutura de ocupação da região metropolitana de Salvador. Encontro Regional da ABET, 6 ${ }^{\circ}$ João Pessoa, 2007.Anais... João Pessoa: ABET, 2007. 
MINISTÉRIO DA PREVIDÊNCIA SOCIAL (MPS). Regime geral da Previdência Social - RGPS. Perguntas Frequentes. Disponível em: <http:// www.previdencia.gov.br/ouvidoria-geral-da-previdencia-social/perguntasfrequentes/>Acessoem: 15/07/2014.

NAJBERG, S.; IKEDA, M. Previdência no Brasil: desafios e limites. A economia brasileira nos anos, v. 90, n. 1, p. 261-290, 1999. Disponível em: <http://www.bndespar.gov.br/SiteBNDES/export/sites/default/bndes_pt/Galerias/Arqui vos/conhecimento/livro/eco90_08.pdf>. Acesso em 18/08/2014.

NAKAHODO, S. N.; SAVOIA, J. R. A reforma da previdência no Brasil: estudo comparativo dos governos Fernando Henrique Cardoso e Lula. Revista Brasileira de Ciências Sociais, v. 23, n. 66, p. 45-58, 2008. Disponível em: <http:// www.scientificcircle.com/pt/44577/reforma-previdencia-brasil-estudo-comparativogovernos-lula/>. Acessoem: 18/07/2014.

NARITA, R. Self Employment in Developing Countries: a Search-Equilibrium Approach.Departamento de Economia, FEA-USP, 2013.

NERI, M. et al. Em busca de incentivos para atrair o trabalhador autônomo para a Previdência Social. Nova Economia, v. 17, n. 3, p. 363-394, 2007. Disponível em: <http://www.scielo.br/scielo.php?script=sci_arttext\&pid=S010363512007000300001\&lng=en\&nrm=iso>. Acesso em: 10/04/2014.

NORONHA, J. C. Os rumos do Estado Brasileiro e o SUS: a seguridade social como política pública da sociedade e estado. Saúde e Sociedade, v. 14, n. 2, p. 31-38, 2005. Disponível em: <http://www.scielo.br/pdf/sausoc/v14n2/04.pdf>. Acesso em: $14 / 09 / 2014$.

OLIVEIRA, F. E. B.; BELTRÃO K. I. Basic issues in reforming social securitysystems. IPEA (INSTITUTO DE PESQUISA ECONÔMICA APLICADA).1997. Texto para discussão $\mathrm{N}^{\circ} 535$.

OLIVEIRA, F. E. B.; BELTRÃO K. I. Brazil: The Brazilian Social Security System. International Social Security Review, v.54, n. 1, p. 101-112, 2001. Disponível em: http://onlinelibrary.wiley.com/doi/10.1111/1468-246X.00087/abstract. Acesso em: 12/08/2014.

OLIVEIRA, J.; TEIXEIRA, S. M. F. A (im) previdência social brasileira. Rio de Janeiro: ABRASCO/Vozes, 1986.

OUTREVILLE, J. F. Risk aversion, risk behavior and demand for insurance: A survey. Canada: International Center ForEconomicResearch (ICER). 2013.

PÅLSSON, A.-M.. Does the degree of relative risk aversion vary with household characteristics?. Journal of economic psychology, v. 17, n. 6, p. 771-787, 1996.Disponivelem:

http://www.sciencedirect.com/science/article/pii/S0167487096000396. Acesso em: $17 / 09 / 2014$. 
PASINATO, M. T. M.. Envelhecimento, ciclo de vida e mudanças socioeconômicas: novos desafios para os sistemas de seguridade social. $221 \mathrm{f}$.. 2009. Tese (Doutorado em Medicina). Instituto de Medicina Social, Universidade do Estado do Rio de Janeiro, Rio de Janeiro,2009.

PASTORE, J. Perspectivas e problemas de emprego no Brasil. Seminário Brasil Canadá: Desafios para a criação de empregos. Brasília, 2005.

PEDERSINI, R., COLETTO, D. Self-employedworkers: industrial relations and working conditions. Dublin: European Foundation for the Improvementof Living andWorkingConditions (Eurofound), 2009.

PINHEIRO, R. P.A demografia dos fundos de pensão. V. 24. Brasília - DF: Coleção Previdência Social, 2007. 292.p.

PORTAL DO EMPREENDEDOR. Atividades Permitidas Disponível em: http://portaldoempreendedor.gov.br/mei-microempreendedor-individual/atividadespermitidas. Acesso em Acesso em: 18/03/2015.

REIS, P. R. C. Política pública de previdência social e o nível de bem estar: Impacto sobre as famílias e municípios de Minas Gerais.2012. 211 f.. Dissertação (Mestrado em Administração). Departamento de Administração, Universidade Federal de Viçosa, Viçosa,2012.

SANTIAGO, C. E. P. Do catador ao doutor: determinantes da informalidade do trabalhador por conta própria no Brasil. 2014. 79 f.. Dissertação (Mestrado em desenvolvimento, sociedade, e cooperação internacional) Centro de Estudos Avançados Multidisciplinares, Universidade Federal de Brasília, 2014.

SIEGEL, F. W.; HOBAN, J. P. Measuring risk aversion: Allocation, leverage, and accumulation. Journal of Financial Research.1991.

SHOWERS, V. E.; SHOTICK, J. A. The effects of household characteristics on demand for insurance: A tobit analysis. Journal of Risk and Insurance, p. 492-502, 1994.

SILVA, A. A... A reforma da previdência social brasileira: entre o direito social e o mercado. São Paulo em perspectiva, v. 18, n. 3, p. 16-32, 2004. Disponível em: <http://www.scielo.br/scielo.php?pid=S0102-88392004000300003\&script=sci_arttext $>$. Acesso em 15/09/2015.

SILVA, P. L. B. MÉDICI, A. C. Seguridade social: velhos problemas, novos desafios. Revista de Administração Pública. V.25, n.4. 1991. p. 69-134.

SILVA, P. L.; PESSOA, D. G. C.; LILA, M. F. Análise estatística de dados da PNAD: incorporando a estrutura do plano amostral. Ciência \& Saúde Coletiva, v. 7 , n. 4, p. 659-670, 2002. Disponível em: <http://www.scielo.br/pdf/csc/v7n4/14597>.

Acesso em: 25/03/2015. 
TRUETT, D. B.; TRUETT, L. J. The demand for life insurance in Mexico and the United States: A comparative study. Journal of Risk and Insurance.1990.

STAM, E. Entrepreneurship and innovation policy. Available at SSRN 1115262, 2008.

Disponível

em:

http://www.fep.up.pt/conferencias/eaepe2007/Papers\%20and\%20abstracts_CD/Stam.pd f>. Acesso em: 26/11/2014.

ULYSSEA, G. Informalidade no mercado de trabalho brasileiro: uma resenha da literatura. IPEA (INSTITUTO DE PESQUISA ECONÔMICA APLICADA).Rio de Janeiro, 2005. Texto para discussão No1070. Disponível em: http://www.ipea.gov.br/ portal/images/stories/PDFs/TDs/td_1070.pdf. Acessoem 17/02/2015.

VARIAN, H. R.; Microeconomic Analysis. $3^{\circ}$ edição. New York: W. W. Norton \& Company, 1992.

VEALL, M. R. Public pensions as optimal social contracts. Journal of Public Economics. 1986.

ZIETZ, E. N. An examination of the demand for life insurance. Risk Management and Insurance Review, v. 6, n. 2, p. 159-191.MiddleTennesseseeStateUniversity, EUA, 2003. 